\title{
PENDUGAAN POLA DISTRIBUSI SPASIO-TEMPORAL TARGET STRENGTH IKAN PELAGIS DENGAN METODE AKUSTIK DI PERAIRAN TELUK TOMINI
}

\author{
Wudianto"), ( Nyoman Arnaya"'), Mohammad Natsir"), dan Dian Herdiana“")
}

\begin{abstract}
ABSTRAK
Penelitian pola distribusi target strength ikan pelagis di perairan Teluk Tomini dilakukan pada bulan Juli sampai dengan Agustus 2003. Hasil penelitian menunjukkan nilai target strength ikan pelagis berkisar antara 60 sampai dengan $-30 \mathrm{~dB}$, dengan nilai dominan antara -60 sampai dengan $-54 \mathrm{~dB}$. Nilai target strength pada perairan dekat pantai lebih didominasi oleh nilai yang kecil, sedangkan untuk nilai yang besar lebih banyak tersebar pada perairan lepas pantai. Besaran nilai target strength terlihat berkorelasi positif dengan kedalaman di mana nilai target strength kecil banyak tercatat di perairan lapisan atas, namun sebaliknya nilai terget strength besar banyak ditemukan pada perairan yang lebih dalam. Hal ini, menunjukkan bahwa ikan berukuran kecil banyak menyebar di perairan lapisan atas, sedangkan ikan yang berukuran besar banyak terdapat di lapisan perairan dalam. Secara temporal, nilai target strength kecil yaitu -60 sampai dengan $-58,5$ $\mathrm{dB}$ tercatat lebih banyak pada siang hari, sedangkan untuk nilai target strength yang lebih besar yaitu -54 sampai dengan - $36 \mathrm{~dB}$ lebih banyak terdeteksi pada malam hari. Hal ini, diduga pada malam hari jenis ikan pelagis besar seperti cakalang dan yellow fin tuna melakukan migrasi vertikal dari lapisan dalam ke lapisan atas sekitar termoklin. Berdasarkan pada hasil konversi nilai target strength, diperoleh dugaan panjang ikan yang dominan berkisar antara 15,0 sampai dengan $22,5 \mathrm{~cm}$ yang merupakan ukuran umum untuk ikan jenis layang (Decapterus spp.). Hal ini, sesuai dengan pengamatan hasil tangkapan, bahwa di perairan Teluk Tomini pada bulan Juli sampai dengan Agustus 2003 didominasi oleh ikan jenis layang, terutama ikan malalugis (Decapterus macarellus).
\end{abstract}

ABSTRACT: Estimation of spatial-temporal distribution pattern of target strength for pelagic fish using acoustical method in Tomini Bay. By: Wudianto, I Nyoman Arnaya, Moh. Natsir, and Dian Herdiana

Research on distribution pattern of target strength for pelagic fish in Tomini Bay was conducted in JulyAugust 2003. Result shows that the target strength for pelagic fish ranged from -60 to $-30 \mathrm{~dB}$ which the dominant values ranged from -60 to $-54 \mathrm{~dB}$. The small target strength was recorded near shore waters, nicontras, the big target strength was found in off shore waters. There was positive correlation between the target strength of fish and water depth. The target strength became high with decreasing water depth, so it indicated that the small fish distributed in the shallow water, however, the large fish distributed in the deep waters. The small size of target strength observed high during day time, nevertheless, the big size of target strength was recorded frequently during night. It showed that the large pelagic fish as skipjack and yellowfin tuna were probably migrated to the surface layer around thermocline during night. Based on the analysis of target strength for estimation of fish length resulted that the dominant fish size in Tomini Bay was ranging between $15.0-22.5 \mathrm{~cm}$. Observation on the length of fish caught in this area during July-August was dominated by scads especially Decapterus macarellus with similar size range.

KEYWORDS: distribution, target strength, pelagic fish, Tomini Bay

\section{PENDAHULUAN}

Teluk Tomini merupakan salah satu teluk yang berkuran besar di wilayah perairan Indonesia dengan luas diperkirakan mencapai $59.500 \mathrm{~km}^{2}$. Secara geografis, Teluk Tomini berada di Pulau Sulawesi tepatnya berhubungan langsung dengan Laut Maluku dan Teluk Tolo, kemudian menyambung dengan Laut Sulawesi dan Laut Banda. Dengan posisi yang demikian ini, diperkirakan terjadi sirkulasi massa air di dalam perairan teluk sehingga mengakibatkan perairan tersebut menjadi subur atau kaya akan nutrien. Perairan Teluk Tomini diduga memiliki potensi sumber daya ikan yang cukup besar, baik jenis ikan pelagis maupun ikan demersal terutama di perairan yang terdapat karang. Salah satu metode yang sudah dikembangkan untuk mengkaji potensi sumber daya ikan adalah metode akustik.
Metode akustik merupakan metode yang pada prinsipnya menggunakan gelombang suara dan perambatannya, serta pantulan yang dihasilkan oleh target yang terdeteksi dalam suatu medium (Johanesson \& Mitson, 1983). Metode ini memiliki beberapa keunggulan diantaranya adalah memperoleh informasi tentang kelimpahan dan distribusi ikan secara cepat dan mencakup kawasan yang luas, pendugaan stok ikan secara langsung, memiliki tingkat ketelitian dan ketepatan yang tinggi, dan tidak berbahaya karena frekuensi yang digunakan tidak membahayakan baik bagi pengguna alat ataupun target (MacLennan, 1990). Beberapa kelemahan antara lain lemah dalam memilah ikan berdasarkan pada spesies, kurang teliti digunakan untuk pengambilan contoh ikan dekat permukaan dan dasar, agak rumit dan kompleks, diperlukan biaya awal yang tinggi, diperlukan pengambilan contoh

\footnotetext{
T Peneliti pada Balai Riset Perikanan Laut, Jakarta

") Dosen Fakultas Perikanan dan Ilmu Kelautan, Institut Pertanian Bogor, Bogor

...) Mahasiswa Fakultas Perikanan dan Ilmu Kelautan, Institut Pertanian Bogor, Bogor
} 
biologi ikan dan kemungkinan terjadi bias saat penentuan target strength dan kalibrasi (Torne, 1983). Oleh karena itu, untuk melengkapi kekurangan dari metode ini diperlukan pengambilan data ikan hasil tangkapan secara in situ sehingga dapat dijadikan sebagai verifikasi data nilai target srength (dalam menentukan ukuran dan jenis ikan) yang diperoleh dari sistem akustik.

Dalam mengestimasi besarnya potensi sumber daya atau biomassa ikan, maka informasi ukuran sangat diperlukan. Ikan dengan ukuran tertentu diperkirakan menyebar berdasarkan pada daerah penangkapan dan waktu baik siang maupun malam hari. Informasi tersebut diperlukan untuk pengembangan usaha penangkapan secara efektif dan efisien. Penelitian ini bertujuan: 1) mengetahui pola distribusi target strength ikan pelagis secara spasial dan temporal (siang dan malam) dan 2) menduga panjang ikan berdasarkan pada konversi nilai target strength

\section{BAHAN DAN METODE}

Penelitian ini dilakukan pada Juli sampai dengan Agustus 2003 di perairan Teluk Tomini. Sarana penelitian yang digunakan adalah KM. Malalugis dengan ukuran 91 GT dan dilengkapi beberapa peralatan berikut SIMRAD EY-500 scientific split beam echosounder, portable computer dan printer, global positioning system, dan current meter valeport $108 / 308$ plus (dilengkapi dengan CTD), Pengukur panjang ikan (measuring paper, measuring board, dan meteran).

Untuk keperluan pengolahan data digunakan peralatan sebagai berikut personal computer dan printer, perangkat lunak antara lain EP-500, DATALOG, Microsoft Word, Microsoft Excel, dan Surfer Versi 7.0.

Desain survei yang digunakan dalam penelitian ini pada dasarnya adalah berbentuk paralel (systematic parallel transect) dengan sedikit penyesuaian dengan bentuk teluk (MacLennan \& Simmond, 1992). Trek dimulai dari stasiun oseanografi pertama yaitu pada posisi sebelah tenggara Bitung dengan koordinat (125 $15^{\prime}$ BT dan $\left.1^{\circ} 15^{\prime} \mathrm{LU}\right)$ dan berakhir pada stasiun oseanografi ke-34 pada koordinat (122 ${ }^{\circ} 30^{\prime}$ BT dan $0^{\circ} 35^{\prime}$ LS) seperti terlihat pada Gambar 1.

\section{Pengambilan Data}

Pengambilan data akustik dilakukan dengan menggunakan SIMRAD EY-500 split beam echosounder dengan frekuensi $38 \mathrm{kHz}$. Pengambilan data dilakukan secara terus-menerus pada siang dan malam hari selama periode pelayaran dengan kecepatan kapal sekitar 7 knot. Data disimpan setiap 10 menit, sehingga diharapkan tiap file berjarak 1 mil laut. Penentuan elementary sampling distance unit ditetapkan sejauh 1 mil laut. Selain itu, untuk menentukan posisi tiap elementary sampling distance unit dari data akustik digunakan global positioning system. Data akustik dalam bentuk data gram,

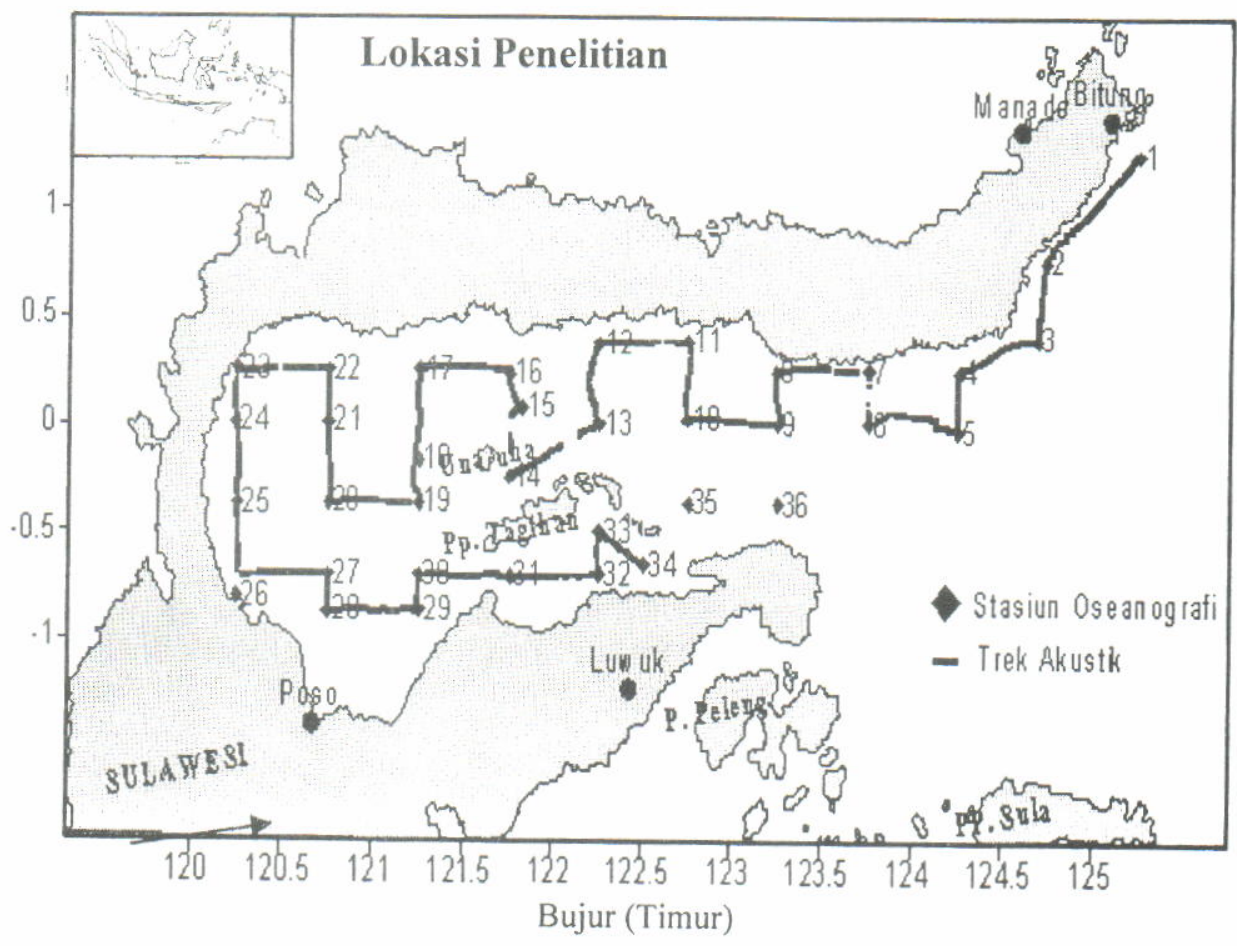

Gambar 1. Peta Teluk Tomini serta desain trek akustik dan posisi stasiun oseanografi.

Figure 1. Map of Tomini bay showing acoustic transect line and oceanographic stations 
kemudian dikompres dengan menggunakan EP-500 dan bantuan donggle menjadi data treshold agar dapat dianalisis.

Pengambilan data ikan dilakukan di tempat pendaratan ikan di 2 daerah yaitu Parigi dan Pagimana, Sulawesi Tengah. Ikan contoh diambil secara acak dari hasil tangkapan pukat cincin sebanyak $40 \mathrm{~kg}$ (1 box). Ikan contoh kemudian disortir menurut spesies dan dihitung jumlah tiap spesiesnya. Pengukuran dilakukan terhadap seluruh ikan contoh. Untuk contoh ikan tuna (cakalang dan yellow fin tuna) diperoleh dari hasil tangkapan pukat cincin dan pancing (handline) di tempat pendaratan ikan. Pengukuran distribusi frekuensi panjang dilakukan terhadap panjang cagak (fork length).

\section{Pengolahan dan Analisis Data}

Data akustik dari SIMRAD EY-500 berupa echogram yang telah dikompres dalam bentuk data treshold, kemudian diolah dengan program EP-500 dan dibagi menjadi beberapa segmen dan 10 strata kedalaman pada menu analysis pelagic layer, yang selanjutnya disimpan dalam format ASCII. Setelah data tersimpan dalam bentuk ASCII, pengolahan dilanjutkan pada lembar Excel. Nilai target strength yang didapat dari target strength distribution dirataratakan pada tiap elementary sampling distance unit, kemudian ditampilkan dalam bentuk grafik untuk melihat penyebaran target strength secara vertikal dan kontur secara horisontal. Secara vertical, dapat dilihat hubungan antara frekuensi, nilai target strength dengan strata kedalaman dan untuk penyebaran target strength secara horisontal dapat dilihat hubungan antara nilai target strength dengan posisi (lintang dan bujur) untuk tiap-tiap strata kedalaman.

Untuk memperoleh distribusi panjang ikan digunakan nilai target strength yang telah dirataratakan. Kemudian dengan menggunakan formula Foote (1987) $T S=20$ Log $L+A$, nilai target strength dikonversi menjadi panjang ikan. Nilai A (normalized target strength) yang digunakan adalah $-80 \mathrm{~dB}$, yaitu untuk jenis ikan yang tidak memiliki gelembung renang (bladderless fish), berdasarkan pada data hasil tangkapan tertinggi adalah ikan malalugis, yang merupakan jenis ikan yang tidak memiliki gelembung renang. Sehingga diasumsikan bahwa semua ikan yang terdeteksi dengan sistem akustik adalah ikan dari jenis yang tidak memiliki gelembung renang.

Data komposisi hasil tangkapan menurut spesies dan panjang ikan, kemudian ditampilkan dalam bentuk histogram untuk melihat jenis dan panjang ikan yang memiliki frekuensi tertinggi. Jenis ikan yang menjadi modus hasil tangkapan akan dijadikan sebagai acuan dalam pengkonversian nilai target strength menjadi panjang ikan.

\section{HASIL DAN BAHASAN}

\section{Distribusi Spasial Target Strength}

Distribusi target strength secara spasial dapat memberikan gambaran tentang jumlah atau frekuensi berdasarkan pada strata kedalaman dan posisi geografi untuk tiap-tiap nilai target strength. Distribusi nilai target strength per strata kedalaman dapat ditampilkan dengan distribusi vertikal target strength, sedangkan untuk distribusi nilai target strength berdasarkan pada posisi geografi dapat ditampilkan dalam bentuk sebaran horisontal.

\section{Distribusi vertikal target strength}

Secara umum, pola distribusi vertikal target strength memperlihatkan suatu kecenderungan penurunan nilai dan jumlah dengan bertambahnya kedalaman. Distribusi tertinggi terdapat pada nilai target strength -60 sampai dengan $-54 \mathrm{~dB}$, artinya hampir pada setiap strata kedalaman nilai-nilai tersebut dijumpai frekuensi yang cukup tinggi. Frekuensi tertinggi dimiliki oleh nilai target strength $-57 \mathrm{~dB}$ dengan total frekuensi 1.546 kemudian nilai target strength $-55,5 \mathrm{~dB}$ dengan total frekuensi $834 \mathrm{di}$ urutan berikutnya (Tabel 1 dan Gambar 2).

Tabel 1. Distribusi frekuensi berdasarkan pada target strength dan strata kedalaman

Table 1. Frequencies distribution by target strength and depth strata

\begin{tabular}{|c|c|c|c|c|c|c|c|c|c|c|c|c|c|c|c|c|c|c|c|c|c|c|}
\hline \multirow{2}{*}{ STRATA } & \multicolumn{21}{|c|}{ Target Strength (dB) } & \multirow{2}{*}{ - TOTAL } \\
\hline & -60 & -58.5 & -57 & -55.5 & -54 & -52.5 & -51 & -49.5 & -48 & -46.5 & -45 & -43.5 & -42 & -40.5 & -39 & -37.5 & 36 & -34.5 & 33 & -31.5 & -30 & \\
\hline $1(5-25 \mathrm{~m})$ & 174 & 83 & 109 & 13 & 10 & 2 & 3 & - & 3 & 1 & - & - & 2 & - & 1 & - & - & - & - & - & - & \\
\hline $2(25-50 \mathrm{~m})$ & 30 & 126 & 345 & 144 & 21 & 9 & 5 & 2 & - & 1 & - & 1 & - & - & - & - & - & 1 & - & - & - & \\
\hline $3(50-75 \mathrm{~m})$ & 14 & 57 & 227 & 171 & 90 & 52 & 39 & 11 & 5 & 4 & 1 & 5 & - & - & 1 & - & - & 1 & - & - & - & \\
\hline $4(75-100 \mathrm{~m})$ & 12 & 34 & 183 & 114 & 60 & 30 & 38 & 13 & 16 & 6 & 4 & 1 & - & - & 1 & - & - & - & - & - & - & \\
\hline $5(100-125 m)$ & 10 & 12 & 139 & 119 & 75 & 37 & 28 & 9 & 8 & 3 & 1 & 1 & 3 & 2 & - & 1 & 1 & - & - & - & - & \\
\hline $6(125-150 \mathrm{~m})$ & 17 & 12 & 152 & 100 & 46 & 22 & 17 & 12 & 2 & 7 & 7 & 3 & 2 & 2 & 1 & - & - & - & - & - & - & \\
\hline $7(150-175 \mathrm{~m})$ & 20 & 5 & 130 & 85 & 53 & 21 & 17 & 12 & 14 & 8 & 9 & 10 & 8 & 10 & 7 & 2 & - & - & - & 1 & - & \\
\hline $8(175-200 \mathrm{~m})$ & 15 & 2 & 125 & 62 & 75 & 17 & 23 & 11 & 13 & 10 & 11 & 8 & 3 & 5 & 7 & 5 & 2 & - & - & 1 & - & \\
\hline $9(200-225 \mathrm{~m})$ & 11 & 1 & 87 & 18 & 60 & 12 & 19 & 8 & 16 & 7 & 15 & 5 & 6 & 6 & 3 & 3 & - & - & 3 & 1 & 2 & \\
\hline $10(225-250 \mathrm{~m})$ & 8 & - & 49 & 8 & 29 & 1 & 14 & 3 & 10 & 6 & 13 & 4 & 4 & 9 & 7 & 5 & 9 & 3 & 3 & - & 1 & \\
\hline TOTAL & 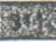 & & 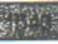 & 63 & & $\mathrm{Pax}$ & & & & & & & & & & & & & & & & \\
\hline
\end{tabular}




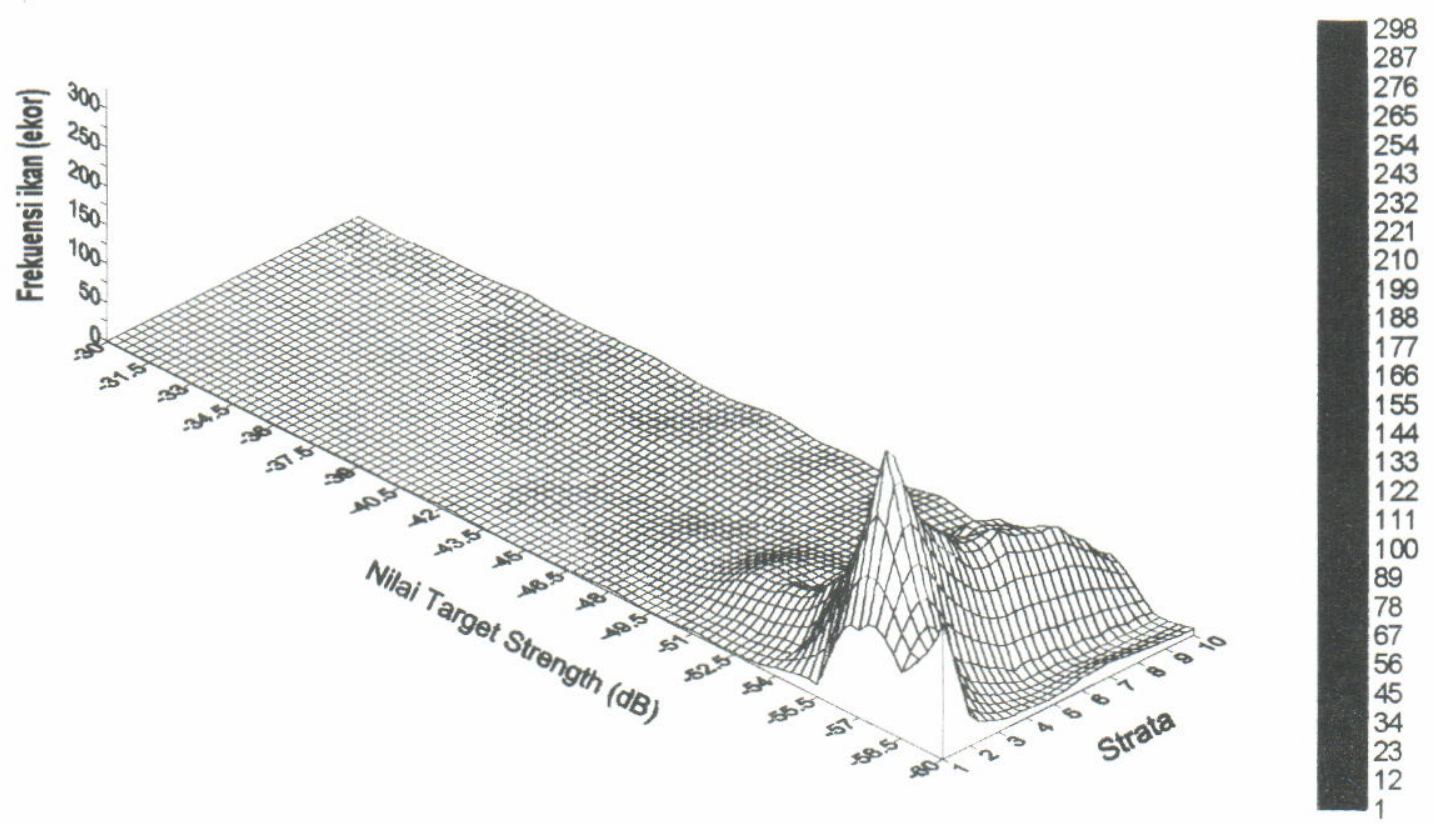

Gambar 2. Distribusi frekuensi berdasarkan pada target strength dan strata kedalaman.

Figure 2. Frequencies distribution by target strength and depth strata.

Frekuensi target strength maksimum terjadi pada strata 2 (25 sampai dengan $50 \mathrm{~m}$ ) dan semakin berkurang pada strata-strata berikutnya. Lebih kecilnya frekuensi target strength pada strata 1 (5 sampai dengan $25 \mathrm{~m}$ ) diduga disebabkan oleh reaksi penghindaran oleh ikan-ikan karena adanya gangguan dari kapal, seperti gerakan kapal, suara dari generator, dan propeler kapal.

Pada lapisan permukaan sampai dengan kedalaman $75 \mathrm{~m}$ (strata 1, 2, dan 3) lebih didominasi oleh nilai target strength yang sedikit kecil, yaitu -60 sampai dengan -54 dB dengan ukuran dugaan panjang ikan antara 10 sampai dengan 19,95 cm. Diduga lapisan ini merupakan swiming layer dari ikanikan pelagis kecil yang bersifat plankton feeder (pemakan plankton). Ikan-ikan pelagis kecil tersebut pada umumnya dari jenis layang, kembung, dan selar.

Berdasarkan pada distribusi nilai suhu dan salinitas untuk 3 strata kedalaman pertama yaitu strata 1 (5 sampai dengan $25 \mathrm{~m}$ ), strata 2 ( 25 sampai dengan $50 \mathrm{~m}$ ), dan 3 (50 sampai dengan $75 \mathrm{~m}$ ) merupakan kisaran nilai yang cukup optimal untuk ikan pelagis. Kisaran rata-rata suhu dan salinitas untuk ke-3 strata tersebut berturut-turut antara 26 sampai dengan $28^{\circ} \mathrm{C}$ dan 34,45 sampai dengan 34,8 psu, yang mana menurut Gunarso (1988) berkisar antara 28 sampai dengan $30^{\circ} \mathrm{C}$. Nilai target strength yang kecil dijumpai pada daerah yang lebih dalam, seperti pada strata 6 (125 sampai dengan $150 \mathrm{~m}$ ) sampai dengan strata $8(175-200 \mathrm{~m})$ dan bahkan untuk target strength dengan nilai $-60,-57$, dan $-55,5$ dB pada strata 10 (225 sampai dengan $250 \mathrm{~m}$ ) di mana suhu perairan sangat dingin yaitu mencapai $\pm 12^{\circ} \mathrm{C}$. Hal ini, diduga ikan-ikan pelagis kecil yang biasa hidup di lapisan permukaan melakukan migrasi vertikal dengan alasan penghindaran dari pemangsaan predator dan lain sebagainya, seperti yang dikemukakan pula oleh MacLennan (1990), bahwa perubahan variasi target strength mungkin disebabkan oleh ikan itu sendiri, selain suhu dan salinitas. Alasan yang lainnya adalah orientasi yang dilakukan oleh ikan-ikan tersebut (head up or head down) yang dapat menyebabkan perubahan posisi sudut ikan terhadap arah datang pulsa suara dari transduser (body tilt angle) yang dapat menurunkan nilai target strength sehingga nilai target strength yang terdeteksi lebih kecil dari ukuran yang sebenarnya.

Untuk nilai-nilai target strength yang lebih besar, yaitu $-49,5$ sampai dengan $-42 \mathrm{~dB}$, dengan dugaan panjang ikan antara 33,49 sampai dengan $79,43 \mathrm{~cm}$ lebih banyak dijumpai pada strata kedalaman di bawah strata 4 (75 sampai dengan $100 \mathrm{~m}$ ) ini disebabkan untuk ikan-ikan pelagis yang memiliki ukuran lebih besar lebih menyukai karakteristik perairan dalam di mana suhu perairan relatif dingin dan nilai salinitas tinggi. Hal ini, sesuai dengan daya adaptasi tubuh ikan dan kebutuhan fisiologisnya. Dari hasil tangkapan diduga ikan-ikan tersebut adalah ikan dari jenis tuna dan cakalang.

Secara keseluruhan sampai dengan kedalaman $250 \mathrm{~m}$, untuk sebaran ikan pelagis di Teluk Tomini pada periode bulan Juli sampai dengan Agustus 2003 memperlihatkan pola sebaran vertikal yang didominasi oleh ikan pelagis kecil, yang ditunjukkan oleh jumlah frekuensi yang besar dengan nilai-nilai target strength yang kecil (ukuran ikan kecil). Oleh karena itu, bahwa faktor oseanografi seperti suhu dan salinitas diduga tidak terlalu berpengaruh terhadap sebaran vertikal ikan pelagis sampai dengan kedalaman $250 \mathrm{~m}$. 


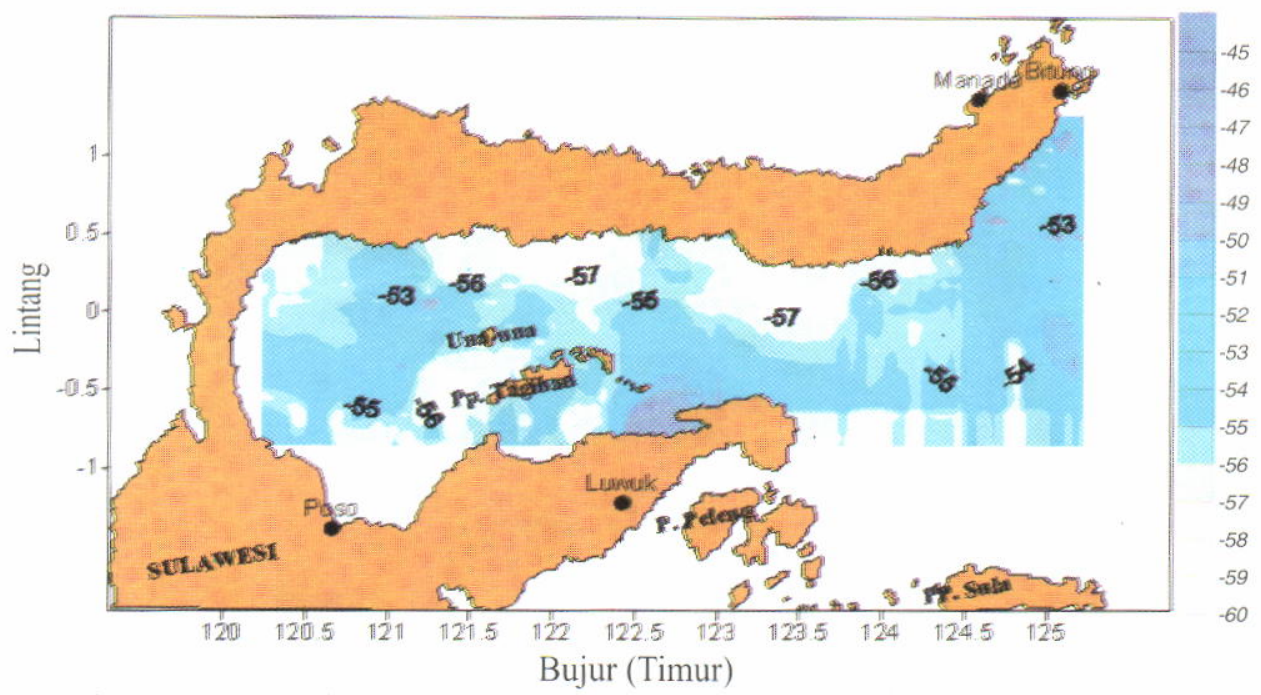

Gambar 3. Distribusi horisontal nilai target strength untuk kedalaman 5 sampai dengan $250 \mathrm{~m}$.

Figure 3. Horizontal distribution of target strength for depth range of 5-250 m.

\section{Distribusi horisontal target strength}

Nilai target strength mulai dari kedalaman 5 sampai dengan $250 \mathrm{~m}$, berkisar antara -60 sampai dengan $-45 \mathrm{~dB}$. Ini berarti bahwa, berdasarkan pada formula Foote (1987) dapat diduga ukuran panjang rata-rata ikan pelagis di perairan Teluk Tomini sampai dengan kedalaman $250 \mathrm{~m}$ berkisar antara 10 sampai dengan 56,23 cm (Gambar 3). Nilai target strength yang kecil pada umumnya terdapat pada daerah dekat pantai dan target strength yang besar terdapat pada daerah yang jauh dari pantai (Gambar 3). Hal ini, diduga ikan-ikan pelagis kecil pada umumnya memilih habitat perairan dekat pantai (neritik), mengingat ikan pelagis kecil pemakan plankton dan plankton lebih melimpah pada daerah dekat pantai di mana pada daerah tersebut konsentrasi nutrien juga tinggi. Berbeda dengan ikan pelagis besar yang lebih menyukai daerah lepas pantai, karena ikan pelagis besar memiliki swimming layer yang luas dan juga dalam. Ikan pelagis besar yang berenang menuju perairan dekat pantai pada umumnya hanya untuk mencari makan.

Distribusi horisontal target strength ditampilkan dalam 10 strata kedalaman dengan interval $25 \mathrm{~m}$, kecuali untuk strata 1 yang dimulai dari kedalaman 5 $\mathrm{m}$ sampai dengan batas bawah sedalam $25 \mathrm{~m}$. Kedalaman maksimal yang dideteksi oleh sistem akustik adalah $250 \mathrm{~m}$, hal ini dikarenakan pada penelitian ini difokuskan untuk mengeksplorasi sumber daya ikan pelagis perairan Teluk Tomini.

Pola distribusi target strength yang diperoleh pada strata 1 (5 sampai dengan $25 \mathrm{~m}$ ) memperlihatkan adanya pengelompokkan nilai target strength, kisaran antara -60 sampai dengan $-42 \mathrm{~dB}$ frekuensi nilai target strength tertinggi terletak pada -60; -58,5; dan $57 \mathrm{~dB}$ dengan jumlah frekuensi berturut-turut 174, 83, dan 109 jika dikonversikan ukuran ikan berukuran panjang 10 sampai dengan $14,12 \mathrm{~cm}$.

Berdasarkan pada modus nilai target strength yang kecil, diduga bahwa pada strata 1 tersebut didominasi oleh ikan-ikan pelagis kecil seperti layang, kembung, dan selar. Ikan-ikan ini lebih banyak berkonsentrasi pada bagian teluk sebelah dalam dengan suhu yang tinggi yaitu sekitar $29,6^{\circ} \mathrm{C}$, sedangkan pada daerah mulut teluk di mana suhu perairan lebih rendah yaitu $26,2^{\circ} \mathrm{C}$ lebih disukai oleh ikan-ikan pelagis yang berukuran lebih besar dengan nilai target strength antara -54 sampai dengan $-42 \mathrm{~dB}$ (panjang dugaan antara 19,95 sampai dengan 79,4 $\mathrm{cm}$ ) dengan frekuensi yang lebih rendah (Gambar 4). Pada daerah mulut teluk, tepatnya sebelah timur Bitung, merupakan daerah penangkapan ikan cakalang. Oleh karena itu, diduga dari nilai target strength yang besar tersebut sebagian besar berasal dari ikan cakalang.

Berbeda dengan strata 1, pada strata 2 (25 sampai dengan $50 \mathrm{~m}$ ) frekuensi maksimum nilai target strength terjadi pada $-58,5 ;-57$; dan $-55,5 \mathrm{~dB}$. Peningkatan nilai target strength tersebut diduga berakibat pula pada peningkatan ukuran ikan yang mendiami strata 2 ini dibandingkan dengan strata 1. Jumlah frekuensi nilai target strength -57 dB 345 , kemudian -55,5 dB 144, dan -58,5 dB 126.

Seperti halnya pada strata 1 , pada strata 2 pun ikan-ikan pelagis yang berukuran kecil terlihat lebih menyukai suhu yang lebih tinggi, yaitu $29^{\circ} \mathrm{C}$ dan salinitas yang lebih rendah yaitu 34,05 psu pada bagian teluk sebelah dalam. Sebaliknya, ikan-ikan pelagis yang berukuran lebih besar, lebih menyukai daerah mulut teluk dengan suhu perairan yang lebih rendah, yaitu $25,8^{\circ} \mathrm{C}$ dengan salinitas yang lebih tinggi, yaitu 35,05 psu (Gambar 5). 


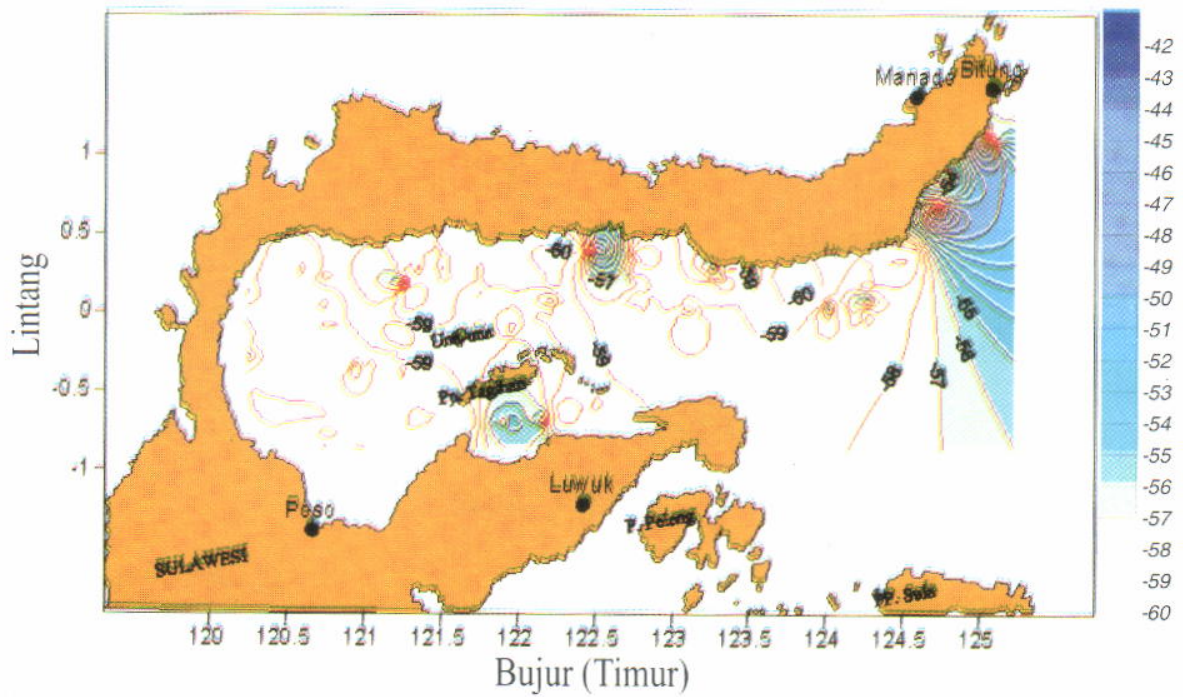

Gambar 4. Distribusi horisontal nilai target strength untuk kedalaman 5 sampai dengan $25 \mathrm{~m}$. Figure 4 Horizontal distribution of target strength for depth range of $5-25 \mathrm{~m}$.

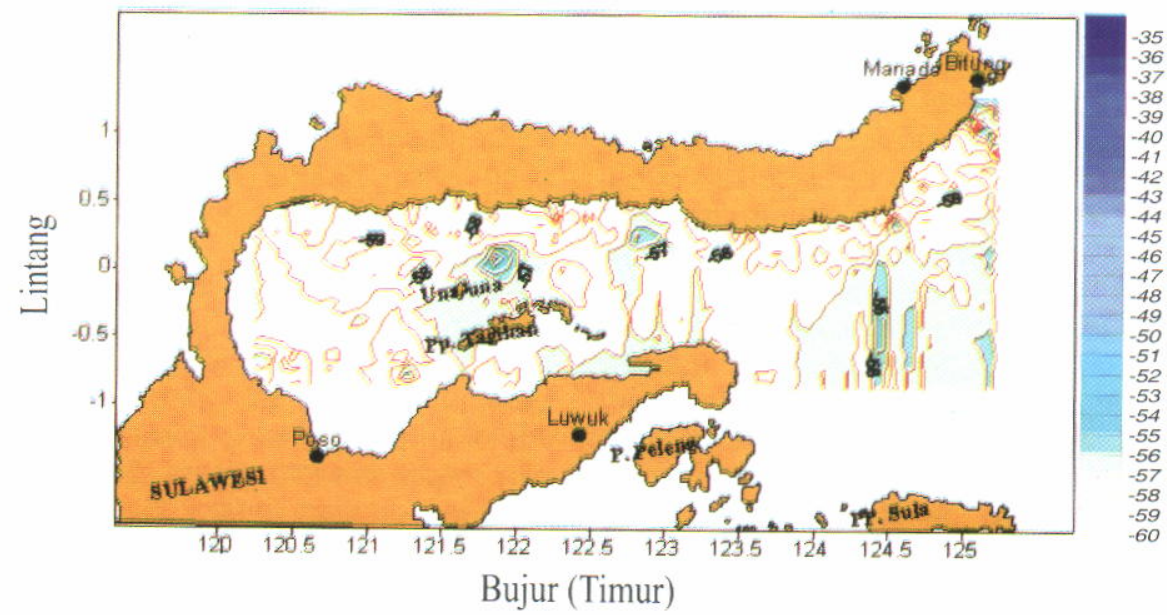

Gambar 5. Distribusi horisontal nilai target strength untuk kedalaman 25 sampai dengan $50 \mathrm{~m}$. Figure 5. Horizontal distribution of target strength for depth range of 25-50 m.

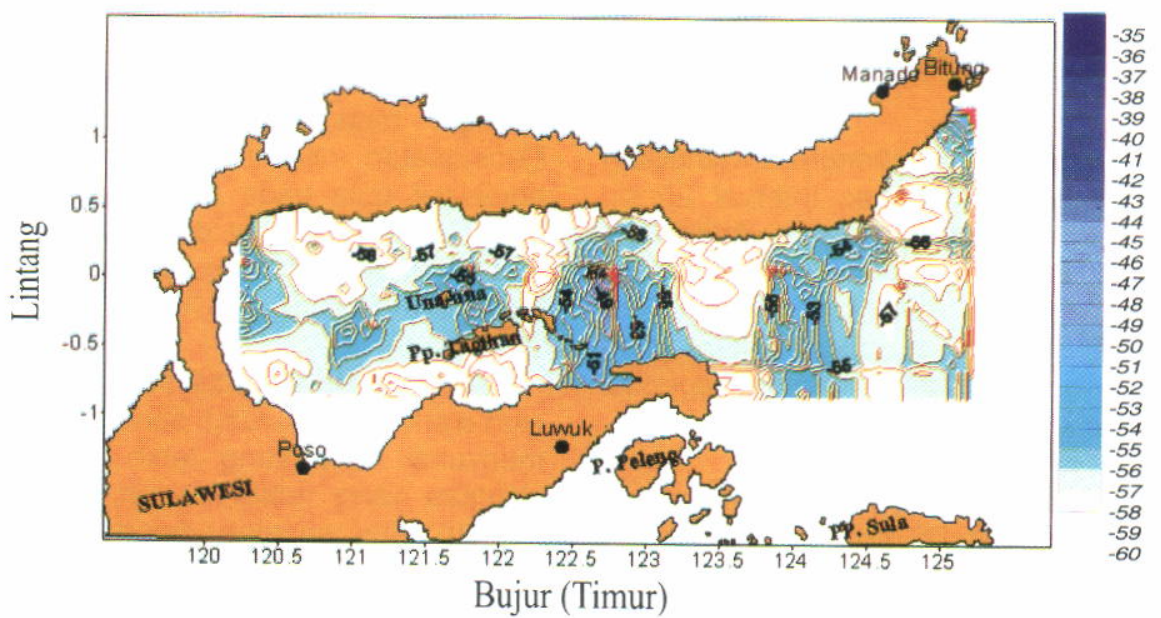

Gambar 6. Distribusi horisontal nilai target strength untuk kedalaman 50 sampai dengan $75 \mathrm{~m}$. Figure 6. Horizontal distribution of target strength for depth range of $50-75 \mathrm{~m}$. 
Gambar 6 menunjukkan distribusi horisontal target strength pada strata 3 (50 sampai dengan $75 \mathrm{~m}$ ) terjadi sedikit perubahan pola sebaran nilai target strength dibandingkan dengan strata sebelumnya. Pada strata ini nilai target strength yang terdeteksi memiliki kisaran antara -60 sampai dengan $-35 \mathrm{~dB}$, dengan frekuensi nilai target strength tinggi berada pada -57 ; $-55,5$; dan $-54 \mathrm{~dB}$ masing-masing dengan frekuensi 227, 717, dan 90. Pada strata ini nilai target strength menyebar baik pada bagian dalam, tengah, dan mulut teluk, dan diikuti dengan pola sebaran suhu dan salinitas yang terkonsentrasi pada berbagai tempat. Kisaran suhu pada strata 3 ini mulai dari 24,4 sampai dengan $27,4^{\circ} \mathrm{C}$ dan salinitas berkisar antara 34,25 sampai dengan 35,25 psu.

Pola distribusi target strength yang sama terjadi pada strata 4 sampai dengan strata 8 , yakni frekuensi tertinggi nilai target strength berada pada $-57 ;-55,5$; dan $-54 \mathrm{~dB}$ meskipun pada 1 sisi kondisi oseanografi terus berubah baik suhu maupun salinitas dengan meningkatnya strata kedalaman. Pada strata 4 (75 sampai dengan $100 \mathrm{~m}$ ) nilai target strength yang terdeteksi berkisar antara -60 sampai dengan -40 dB dan tersebar cukup merata pada seluruh daerah perairan di mana pada strata ini suhu perairan berkisar antara 22 sampai dengan $25,8^{\circ} \mathrm{C}$ dengan kisaran salinitas antara 34,7 sampai dengan 35,65 psu. Pada strata ini frekuensi nilai target strength yang lebih besar meningkat dibandingkan dengan strata sebelumnya (Gambar 7)

Strata 5 (100 sampai dengan $125 \mathrm{~m}$ ) memiliki kisaran target strength antara -60 sampai dengan -36 dB (Gambar 8) dengan kisaran suhu antara 18,6 sampai dengan $22,6^{\circ} \mathrm{C}$ yang menunjukkan penurunan nilai dari strata sebelumnya dengan kondisi yang menyebar. Lain halnya dengan nilai salinitas yang mengalami peningkatan kembali, yaitu dengan kisaran 34,7 sampai dengan 35,8 psu. Kisaran nilai target strength untuk strata 6 (125 sampai dengan $150 \mathrm{~m}$ ) tidak jauh berbeda dengan strata 5 yaitu antara -30 sampai dengan $-39 \mathrm{~dB}$ dengan pola sebaran untuk target strength dengan nilai kecil berada pada bagian teluk sebelah dalam dan target yang berukuran lebih besar berada pada sekitar mulut teluk (Gambar 9).

Kisaran strata yang relatif sama dimiliki oleh strata 7 (150 sampai dengan $175 \mathrm{~m}$ ) dan strata 8 (175 sampai dengan $200 \mathrm{~m}$ ) dengan nilai antara -60 sampai dengan $-32 \mathrm{~dB}$. Di samping memiliki modus nilai target strength yang sama, ke-2 strata ini juga memiliki sebaran nilai target strength lain yang tidak jauh berbeda. Hampir semua nilai target strength mulai dari yang berukuran kecil sampai dengan yang berukuran besar ditemui pada ke-2 strata ini. Kedua strata diduga merupakan daerah yang disukai oleh ikan ikan-ikan pelagis, baik yang berukuran besar maupun kecil. Pada 2 strata ini kisaran suhu adalah 15,4 sampai dengan $18,2^{\circ} \mathrm{C}$ untuk strata 7 dan strata 8 mulai dari 14,2 sampai dengan $16,8^{\circ} \mathrm{C}$ yang menunjukkan nilai suhu yang cukup rendah (Gambar 10 dan 11).

Pola distribusi target strength yang sama juga dimiliki oleh strata 9 (200 sampai dengan $225 \mathrm{~m}$ ) dan strata 10 (225 sampai dengan $250 \mathrm{~m}$ ) yang memiliki kisaran nilai target strength antara -60 sampai dengan $-30 \mathrm{~dB}$ dan frekuensi tertinggi untuk ke-2 strata ini terletak pada $-57,-54$, dan $-51 \mathrm{~dB}$. Pada ke-2 strata ini frekuensi untuk tiap nilai target strength memiliki jumlah yang lebih seragam dibandingkan dengan strata sebelumnya, di mana pada ke-2 strata ini hampir semua nilai target strength dapat dijumpai. Lebih tingginya frekuensi untuk nilai target strength yang besar menunjukkan bahwa ikan-ikan pelagis yang berukuran besar lebih menyukai perairan dalam, dengan suhu yang rendah dan salinitas yang tinggi. Kisaran suhu dan salinitas pada strata 9 ini berturut-

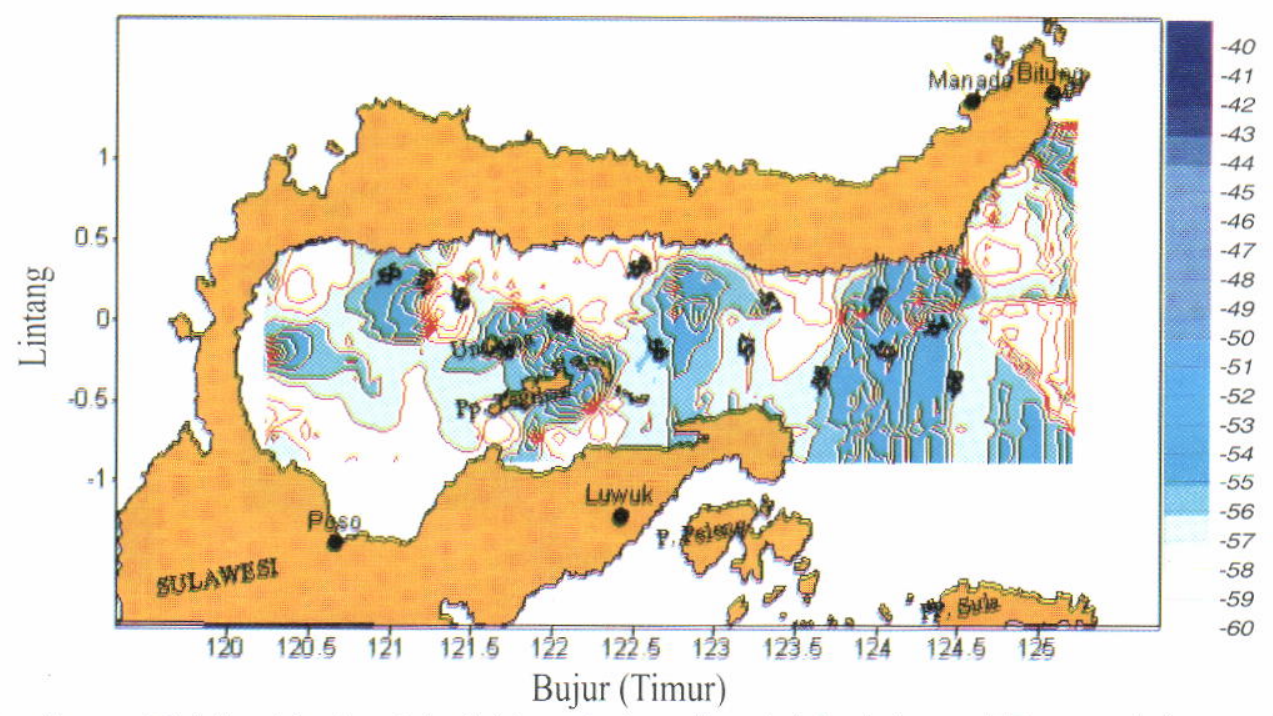

Gambar 7. Distribusi horisontal nilai target strength untuk kedalaman 75 sampai dengan $100 \mathrm{~m}$

Figure 7. Horizontal distribution of target strength for depth range of $75-100 \mathrm{~m}$. 


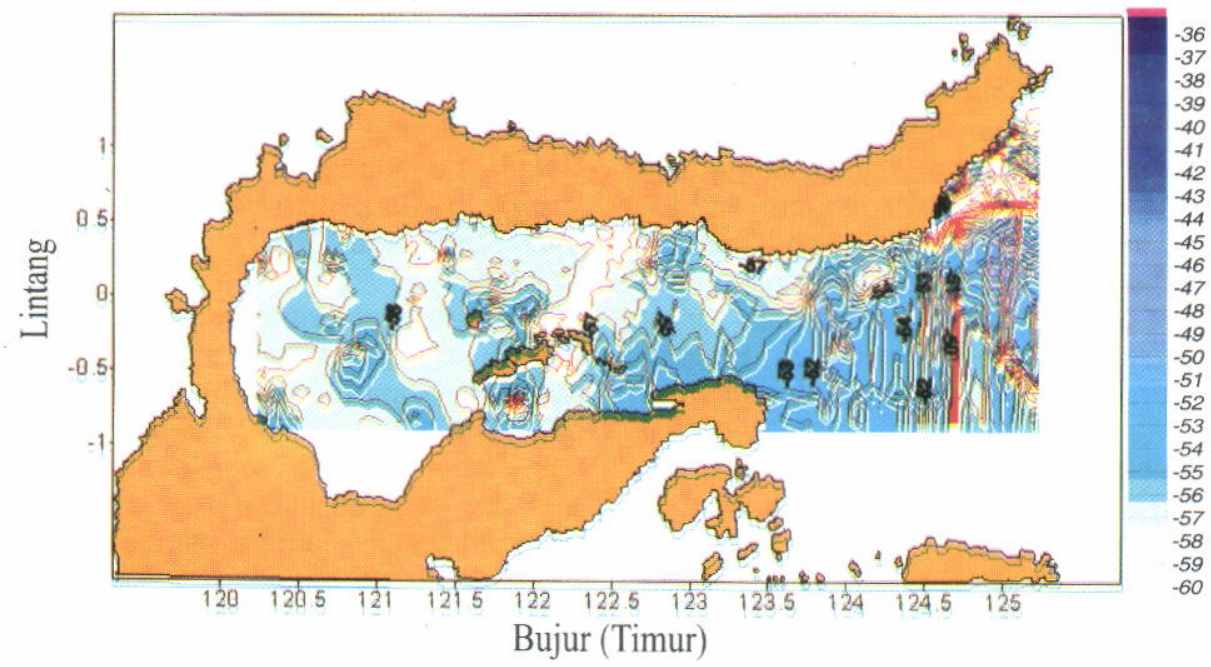

Gambar 8. Distribusi horisontal nilai target strength untuk kedalaman 100 sampai dengan $125 \mathrm{~m}$. Figure 8. Horizontal distribution of target strength for depth range of 100-125 m.

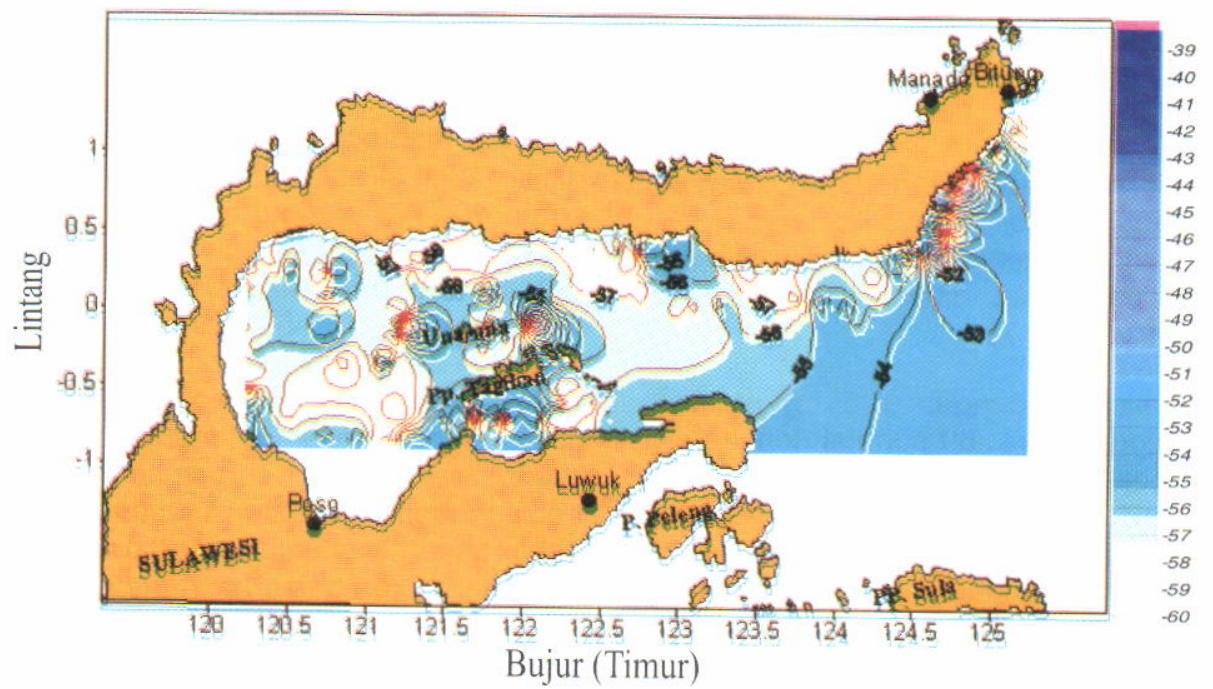

Gambar 9. Distribusi horisontal nilai target strength untuk kedalaman 125 sampai dengan $150 \mathrm{~m}$. Figure 9. Horizontal distribution of target strength for depth range of $125-150 \mathrm{~m}$.

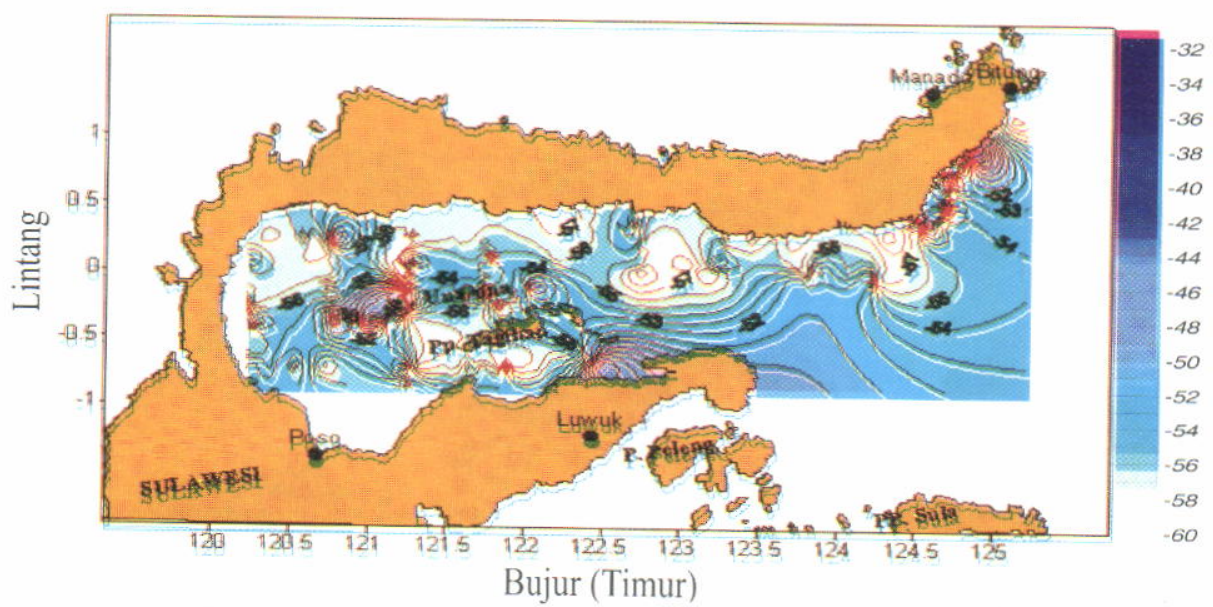

Gambar 10. Distribusi horisontal nilai target strength untuk kedalaman 150 sampai dengan $175 \mathrm{~m}$. Figure 10. Horizontal distribution of target strength for depth range of $150-175 \mathrm{~m}$. 


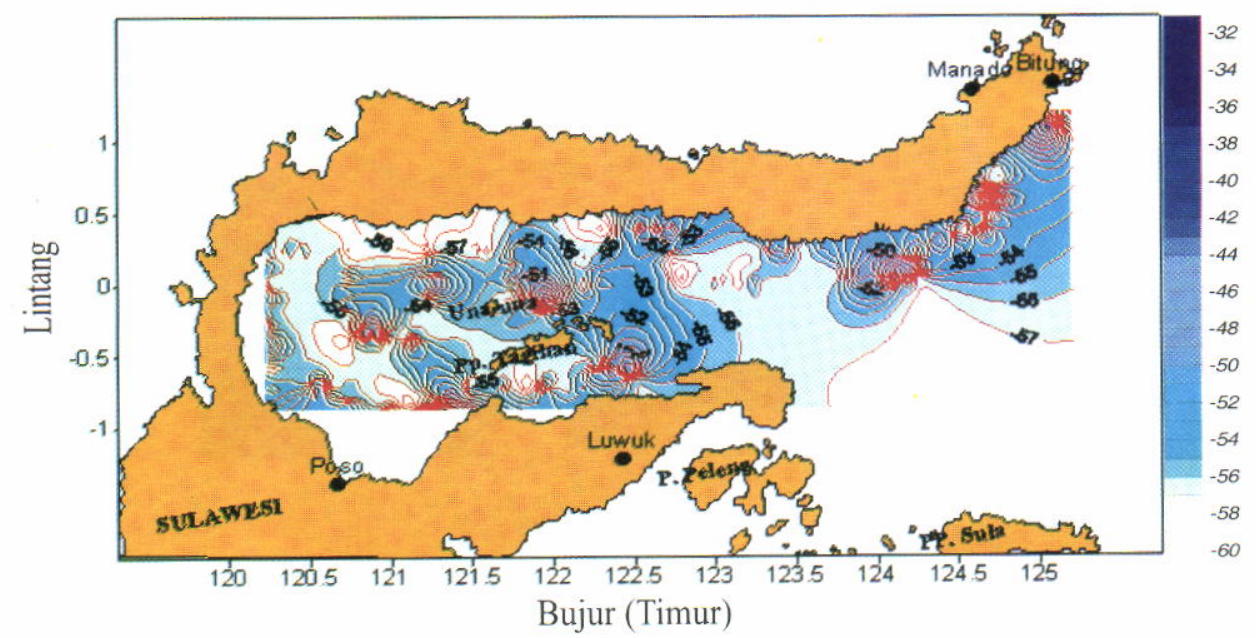

Gambar 11. Distribusi horisontal nilai target strength untuk kedalaman 175 sampai dengan $200 \mathrm{~m}$. Figure 11. Horizontal distribution of target strength for depth range of $175-200 \mathrm{~m}$.

turut sebesar 13 sampai dengan $14,9^{\circ} \mathrm{C}$ dan 34,94 sampai dengan 35,36 psu, sedangkan untuk strata 10 suhu berkisar antara 12,4 sampai dengan $13,5^{\circ} \mathrm{C}$ dan salinitas berkisar antara 34,95 sampai dengan 35,45 psu. Diduga pada ke-2 strata ini jenis-jenis ikan pelagis besar seperti tuna dan cakalang lebih melimpah dibandingkan dengan strata-strata sebelumnya, dengan ukuran dugaan lebih dari 100 $\mathrm{cm}$ (nilai target strength lebih dari -39 dB). Ikan-ikan pelagis besar ini cenderung terkonsentrasi pada daerah yang lebih jauh dari pantai dan terkonsentrasi pada daerah-daerah tertentu, seperti terlihat pada Gambar 12 dan 13 di bawah ini.

Secara umum, dari ke-10 strata kedalaman (5 sampai dengan $250 \mathrm{~m}$ ), nilai target strength banyak didominasi oleh nilai yang kecil, yaitu antara -60 sampai dengan -54 dB dengan ukuran dugaan panjang ikan antara 10 sampai dengan $19,95 \mathrm{~cm}$. Hal ini, diduga di perairan Teluk Tomini pada periode bulan Juli sampai dengan Agustus 2003 ikan-ikan pelagis kecil atau ikan pelagis yang berukuran kecil lebih mendominasi perairan dan beberapa di antaranya mempunyai kisaran toleransi yang cukup luas terhadap suhu dan salinitas, terbukti dengan ditemukannya target strength yang berukuran kecil 57; $-55,5$; dan $-54 \mathrm{~dB}$ pada setiap strata kedalaman dan bahkan dalam jumlah frekuensi yang tinggi.

\section{Distribusi Temporal Target Strength (Siang dan Malam)}

Sifat ikan pelagis yang fototaksis menyebabkan sebaran ikan-ikan ini dipengaruhi oleh intensitas cahaya yang masuk ke dalam laut, sehingga diduga menyebabkan perbedaan pola sebaran antara siang dan malam hari.

Dari pengamatan yang telah dilakukan 697 elementary sampling distance unit terdiri atas 336 elementary sampling distance unit diambil pada siang hari dan 361 elementary sampling distance unit diambil pada malam hari. Penentuan periode pengambilan data untuk siang hari dimulai pada pukul $06^{01}$ sampai dengan pukul $18^{00}$ WIT, sedangkan untuk periode malam hari dimulai dari pukul $18^{01}$ sampai dengan pukul 06 . $^{00}$ WIT

Distribusi target strength ikan pelagis pada periode siang hari yang diperoleh dari 336 elementary sampling distance unit memiliki total frekuensi ikan yang terdeteksi 1.929 ekor, sedangkan pada periode malam hari yang diperoleh dari 361 elementary sampling distance unit memiliki total frekuensi ikan 2.474 ekor. Perbedaan jumlah elementary sampling distance unit menyebabkan total frekuensi ikan yang jauh berbeda antara siang dan malam hari, oleh karena itu perbandingan jumlah target strength didasarkan pada frekuensi relatif untuk masingmasing nilai dan stratanya.

Berdasarkan pada Gambar 14 terlihat bahwa jumlah individu untuk nilai target strength yang kecil ( -60 sampai dengan $-57 \mathrm{~dB}$ ) lebih banyak pada siang hari dibandingkan dengan malam hari. Hal ini, disebabkan siang hari pada umumnya ikan pelagis, terutama ikan pelagis kecil cenderung berenang ke lapisan perairan yang lebih dalam untuk menghindari peningkatan suhu permukaan akibat penyinaran matahari, sehingga menyebabkan perubahan orientasi (head down) yang dapat menurunkan nilai target strength dari nilad yang sebenarnya. Sedangkan untuk nilai target strength yang lebih besar, pada malam hari terlihat lebih banyak daripada siang hari. Pada malam hari ikan pelagis, terutama yang berukuran besar pada umumnya melakukan migrasi vertikal dari lapisan bawah ke lapisan yang lebih atas sehingga menyebabkan jumlah target strength yang berukuran besar lebih banyak terdeteksi pada malam hari. Seperti yang dikemukakan pula oleh Laevastu \& Hayes (1981), bahwa salah satu sifat ikan pelagis, yaitu pada malam hari ikan pelagis yang berada pada 


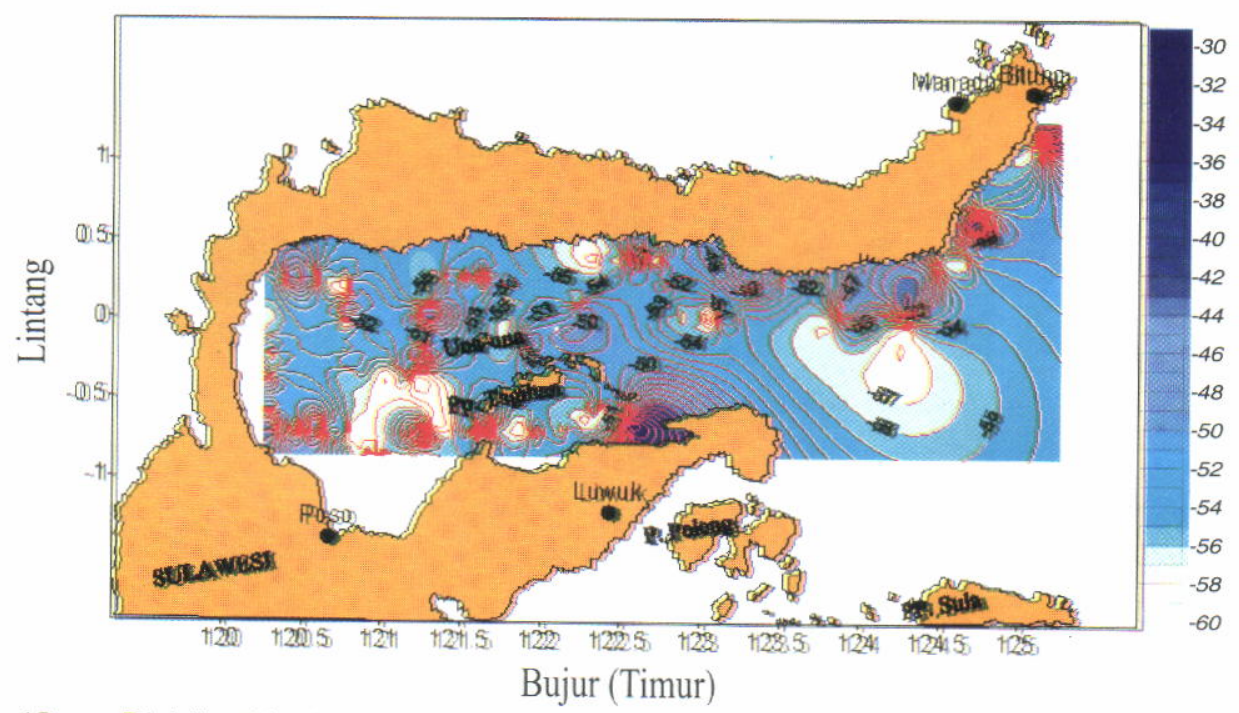

Gambar 12. Distribusi horisontal nilai target strength untuk kedalaman 200 sampai dengan $225 \mathrm{~m}$. Figure 12. Horizontal distribution of target strength for depth range of 200-225 m.

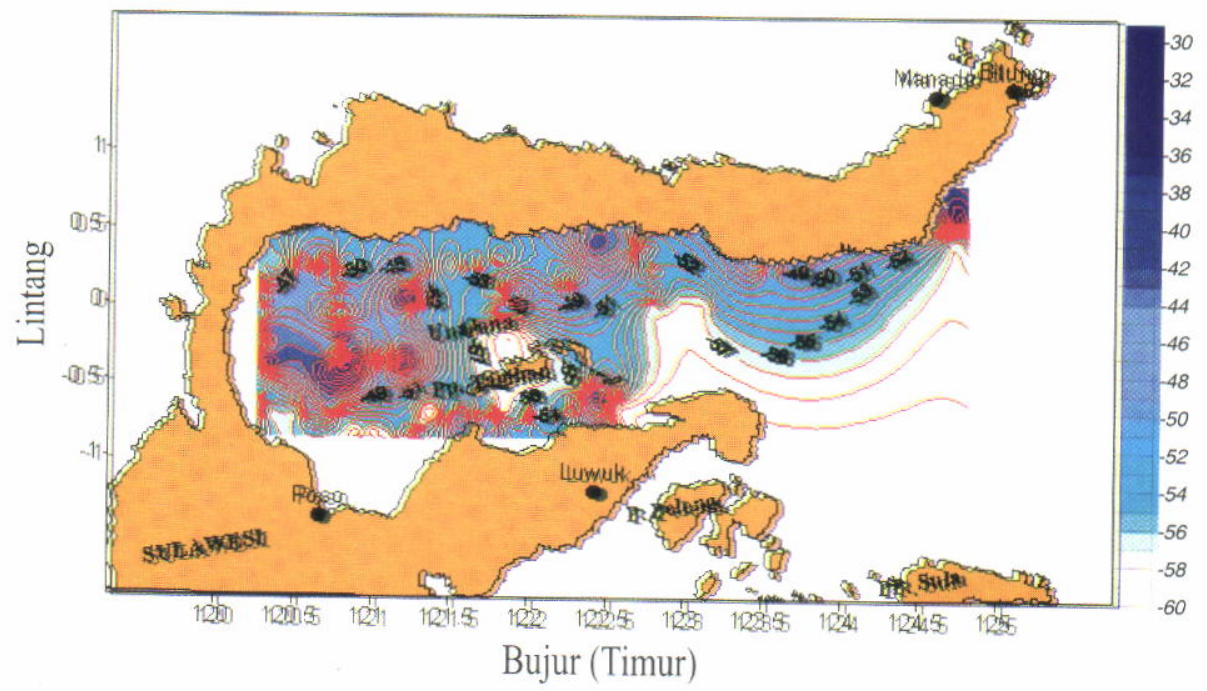

Gambar 13. Distribusi horisontal nilai target strength untuk kedalaman 225 sampai dengan $250 \mathrm{~m}$. Figure 13. Horizontal distribution of target strength for depth range of 225-250 m.

lapisan bawah naik ke lapisan termoklin atau ke atas lapisan termoklin. Migrasi vertikal yang dilakukan oleh ikan pelagis pada malam hari ini dapat disebabkan oleh sifatnya yang nokturnal maupun fototaksis.

Secara umum, antara periode siang dan malam hari pola sebaran nilai target strength tidak jauh berbeda, keduanya memperlihatkan pola penurunan jumlah frekuensi ikan seiring dengan bertambahnya kedalaman dan nilai target strength. Baik siang hari maupun malam hari, frekuensi ikan maksimum pada strata 2 ( 5 sampai dengan $25 \mathrm{~m}$ ). Total frekuensi pada siang dan malam hari berturut-turut 327 ekor dan 360 ekor. Jumlah frekuensi ikan terus berkurang dengan bertambahnya kedalaman. Pada strata 3 (25 sampai dengan $50 \mathrm{~m}$ ) jumlah frekuensi sedikit mengalami penurunan yaitu 321 ekor untuk periode siang hari dan 357 ekor untuk periode malam hari, dan jumlah frekuensi target strength terus berkurang sampai dengan strata 10 (225 sampai dengan $250 \mathrm{~m}$ ) dengan jumlah frekuensi 91 ekor untuk periode siang hari dan 95 ekor untuk periode malam hari (Tabel 3 dan 4 serta Gambar 15).

Dari Tabel 3 dan 4 serta Gambar 15 di atas, terlihat untuk strata kedalaman 1 (5 sampai dengan $25 \mathrm{~m}$ ) frekuensi ikan pada siang hari lebih rendah dibandingkan pada malam hari. Hal ini, diduga karena ikan-ikan pelagis yang berukuran kecil yang berada di permukaan melakukan migrasi vertikal menuju lapisan di bawahnya untuk menghindari lapisan permukaan yang semakin relatif panas akibat semakin banyaknya bahang yang diserap oleh air laut pada siang hari dan juga untuk menghindari cahaya bagi ikan-ikan pelagis kecil yang bersifat fototaksis negatif. Ikan-ikan tersebut diduga melakukan migrasi sampai dengan 


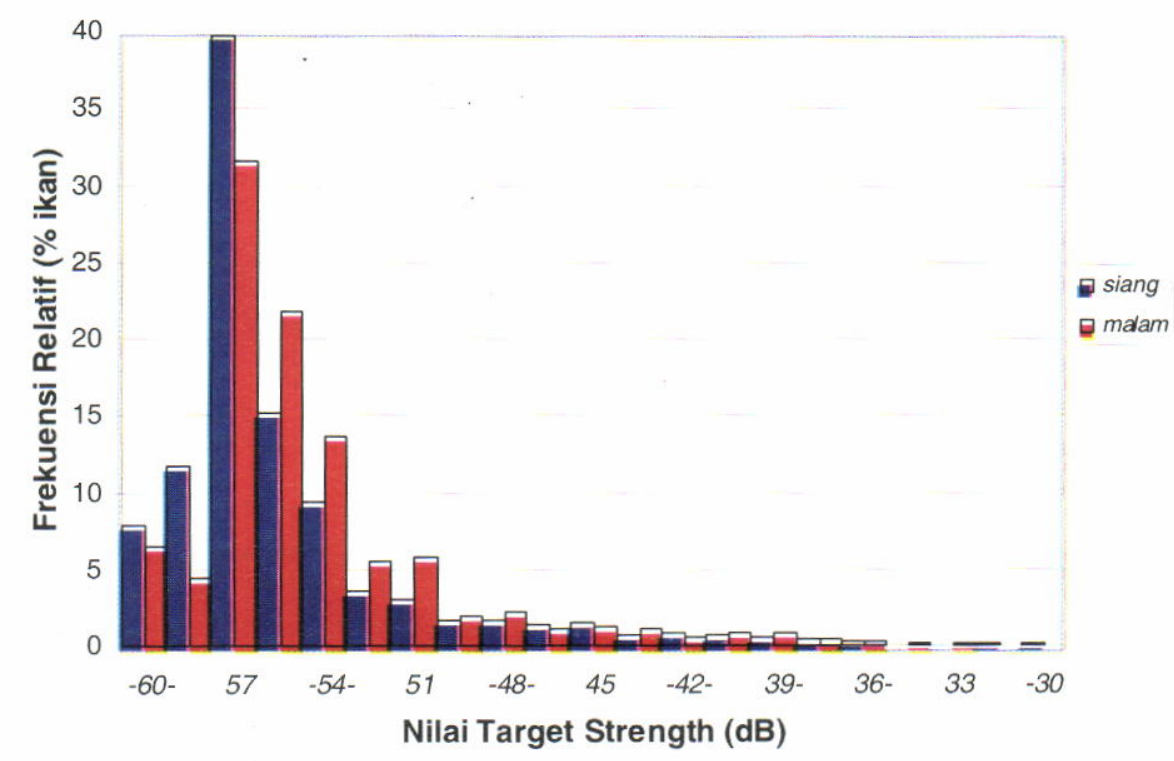

Gambar 14. Histogram frekuensi target strength pada siang dan malam hari. Figure 14. Frequencies histogram for target strength during day and night.

Tabel 3. Distribusi frekuensi berdasarkan pada target strength dan strata kedalaman saat siang hari Table 3. Frequencies distribution according to target strength and depth strata during day time

\begin{tabular}{|c|c|c|c|c|c|c|c|c|c|c|c|c|c|c|c|c|c|c|c|c|c|c|}
\hline \multirow{2}{*}{ STRATA } & \multicolumn{21}{|c|}{ Target Strength (dB) } & \multirow{2}{*}{ TOTAL } \\
\hline & -60 & -58.5 & -57 & -55.5 & -54 & -52.5 & -51 & -49.5 & -48 & -46.5 & -45 & -43.5 & -42 & -40.5 & -39 & -37.5 & -36 & -34.5 & -33 & -31.5 & 30 & \\
\hline $1(5-25 \mathrm{~m})$ & 68 & 15 & 23 & 2 & 4 & 1 & 2 & - & 1 & - & - & - & 1 & - & - & - & - & - & - & - & - & 111 \\
\hline $2(25-50 \mathrm{~m})$ & 26 & 102 & 153 & 29 & 9 & 6 & 2 & - & - & - & - & - & - & - & - & - & - & - & - & - & - & 327 \\
\hline $3(50-75 \mathrm{~m})$ & 10 & 57 & 169 & 61 & 16 & 2 & 4 & 1 & - & 1 & - & - & - & - & - & - & - & - & - & - & - & 321 \\
\hline $4(75-100 \mathrm{~m})$ & 11 & 32 & 88 & 35 & 13 & 10 & 2 & 3 & 3 & 1 & - & - & - & - & - & - & - & - & - & - & - & 198 \\
\hline $5(100-125 m)$ & 5 & 8 & 65 & 43 & 21 & 11 & 6 & 4 & 5 & 2 & - & - & 1 & 2 & - & 1 & - & - & - & - & - & 174 \\
\hline $6(125-150 \mathrm{~m})$ & 8 & 8 & 68 & 39 & 18 & 11 & 8 & 5 & 2 & 6 & 5 & 2 & 1 & 2 & 1 & - & - & - & - & - & - & 184 \\
\hline $7(150-175 m)$ & 5 & 2 & 67 & 40 & 30 & 12 & 9 & 3 & 3 & 2 & - & 2 & 3 & 3 & 3 & - & - & - & - & . & - & \\
\hline $8(175-200 \mathrm{~m})$ & 10 & 1 & 62 & 33 & 38 & 8 & 13 & 7 & 4 & 6 & 4 & 2 & 1 & 1 & - & 1 & 2 & - & - & 1 & - & 494 \\
\hline $9(200-225 \mathrm{~m})$ & 7 & - & 43 & 9 & 19 & 6 & 8 & 7 & 10 & 5 & 8 & 3 & 5 & 3 & 1 & 3 & - & - & - & 1 & 1 & \\
\hline $10(225-250 \mathrm{~m})$ & 2 & - & 27 & 3 & 12 & 1 & 5 & 2 & 4 & 3 & 12 & 3 & 3 & 1 & 5 & 2 & 3 & 1 & 1 & - & 1 & \\
\hline TOTAL & 152 & 226 & 2765 & 294 & 180 & 88 & 986 & 59 & 33 & 26 & 29 & $\mathrm{~F}$ & $y$ & 12 & 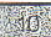 & (3) & 575 & (3) & 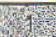 & 2 & 2 & $\sqrt{1928}$ \\
\hline
\end{tabular}

Tabel 4. Distribusi frekuensi berdasarkan pada target strength dan strata kedalaman saat malam hari Table 4. Frequencies distribution according to target strength and depth stratum during night time

\begin{tabular}{|c|c|c|c|c|c|c|c|c|c|c|c|c|c|c|c|c|c|c|c|c|c|c|}
\hline \multirow{2}{*}{ STRATA } & \multicolumn{21}{|c|}{ Target Strength (dB) } & \multirow{2}{*}{ - TOTAL } \\
\hline & -60 & -58.5 & -57 & -55.5 & -54 & -52.5 & -51 & -49.5 & -48 & -46.5 & -45 & -43.5 & -42 & -40.5 & -39 & -37.5 & -36 & -34.5 & -33 & -31.5 & 30 & \\
\hline $1(5-25 m)$ & 106 & 68 & 86 & 11 & 6 & 1 & 1 & - & 2 & 1 & - & - & 1 & - & 1 & - & $\cdot$ & - & - & - & - & 284 \\
\hline $2(25-50 \mathrm{~m})$ & 4 & 25 & 193 & 115 & 12 & 3 & 3 & 2 & - & 1 & - & 1 & - & - & - & - & - & 1 & - & - & - & 360 \\
\hline $3(50-75 \mathrm{~m})$ & 4 & - & 58 & 110 & 74 & 50 & 35 & 10 & 5 & 3 & 1 & 5 & - & - & 1 & - & - & 1 & - & - & - & $35 \%$ \\
\hline $4(75-100 \mathrm{~m})$ & 1 & 2 & 95 & 79 & 47 & 20 & 36 & 10 & 13 & 5 & 4 & 1 & - & - & 1 & - & - & - & - & - & - & 314 \\
\hline $5(100-125 \mathrm{~m})$ & 5 & 4 & 74 & 76 & 54 & 26 & 22 & 5 & 3 & 1 & 1 & 1 & 2 & - & - & - & 1 & - & - & - & - & 245 \\
\hline $6(125-150 \mathrm{~m})$ & 9 & 4 & 84 & 61 & 28 & 11 & 9 & 7 & - & 1 & 2 & 1 & 1 & - & - & - & - & - & - & - & - & 298 \\
\hline $7(150-175 m)$ & 15 & 3 & 63 & 43 & 23 & 9 & 8 & 9 & 11 & 6 & 9 & 8 & 5 & 7 & 4 & 2 & - & - & - & 1 & - & \\
\hline $8(175-200 \mathrm{~m})$ & 5 & 1 & 63 & 29 & 37 & 9 & 10 & 4 & 9 & 4 & 7 & 6 & 2 & 4 & 7 & 4 & - & - & - & - & - & \\
\hline $9(200-225 \mathrm{~m})$ & 4 & 1 & 44 & 9 & 41 & 6 & 11 & 1 & 6 & 2 & 7 & 2 & 1 & 3 & 2 & - & - & - & 3 & - & 1 & \\
\hline $10(225-250 \mathrm{~m})$ & 6 & - & 22 & 5 & 17 & - & 9 & 1 & 6 & 3 & 1 & 1 & 1 & 8 & 2 & 3 & 6 & 2 & 2 & - & - & \\
\hline
\end{tabular}




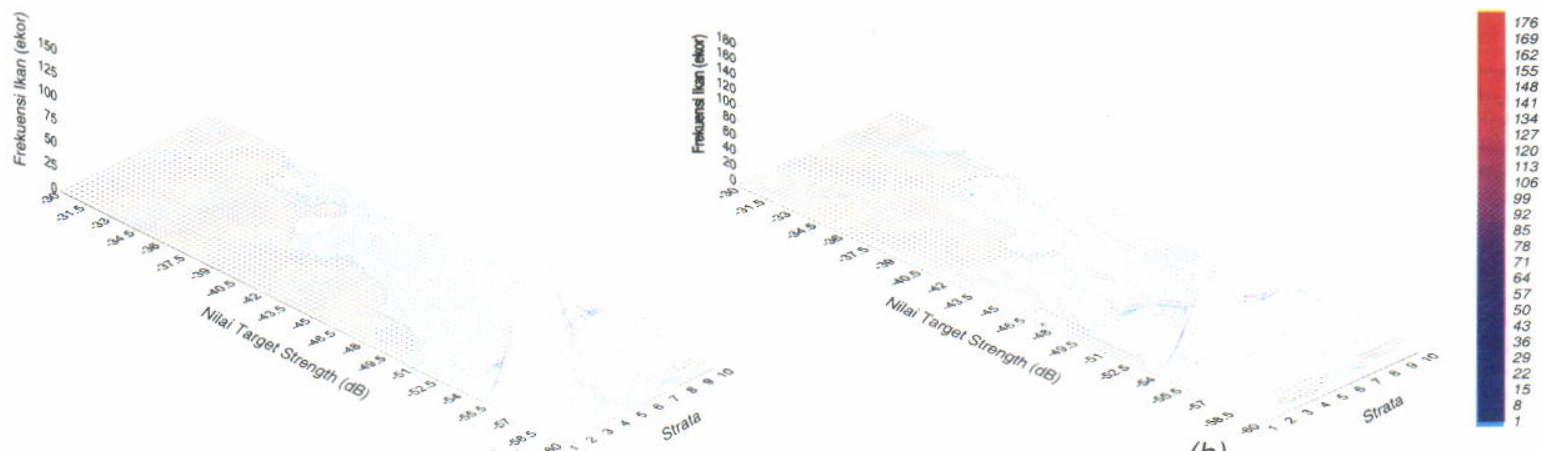

(a)

(b)

Gambar 15. Distribusi frekuensi berdasarkan pada target strength dan strata kedalaman (a) siang; (b) malam.

Figure 15. Frequencies distribution according to target strength and depth strata (a) day time; (b) night time.

strata 2 (25 sampai dengan $50 \mathrm{~m}$ ) dan strata 3 (50 sampai dengan $75 \mathrm{~m}$ ), oleh karena itu pada ke-2 strata ini frekuensi ikan yang ditemui lebih banyak dari strata-strata kedalaman yang lainya.

Perbedaan distribusi nilai target strength terlihat lebih jelas antara siang dan malam hari berdasarkan pada besar kecilnya nilai target strength. Pada siang hari untuk target strength dengan ukuran yang besar -48 sampai dengan $-42 \mathrm{~dB}$ (panjang ikan antara 38,81 sampai dengan $79,43 \mathrm{~cm}$ ), lebih tersebar pada strata perairan yang lebih dalam yaitu pada strata 6 (125 sampai dengan $150 \mathrm{~m}$ ), sedangkan pada malam hari nilai-nilai target strength tersebut tersebar pada strata kedalaman yang lebih rendah, yaitu pada strata 3 (50 sampai dengan $75 \mathrm{~m}$ ). Begitu pula untuk nilai target strength yang sangat besar, yaitu antara -36 sampai dengan -30 dB lebih banyak terlihat pada malam hari dibandingkan dengan siang hari. Ikan-ikan pelagis besar ini diduga dari jenis tuna, karena tuna pada umumnya hidup pada perairan yang dalam (lebih dari $250 \mathrm{~m}$ ) yang sewaktu-waktu melakukan migrasi ke lapisan yang lebih atas untuk mencari makanan dan biasanya pada malam hari. Oleh karena itu, ikan-ikan pelagis besar lebih banyak terdeteksi oleh sistem akustik pada malam hari dibandingkan dengan siang hari.

\section{Dugaan Ukuran Panjang Ikan}

Nilai target strength mempunyai hubungan yang positif dengan ukuran atau panjang ikan. Untuk spesies yang sama, pada umumnya semakin besar ukuran ikan, maka nilai target strength juga semakin besar. Dugaan ukuran panjang ikan dapat digunakan sebagai faktor skala (scalling factor) dalam menentukan densitas dan biomassa ikan yang ada di suatu perairan

Dari pengambilan contoh hasil tangkapan (Gambar 16 dan 17) memperlihatkan sebaran panjang ikan antara 12,5 sampai dengan $72,5 \mathrm{~cm}$. Ikan malalugis merupakan spesies ikan dengan komposisi tertinggi $(30,74 \%)$ dan memiliki kisaran panjang antara 15

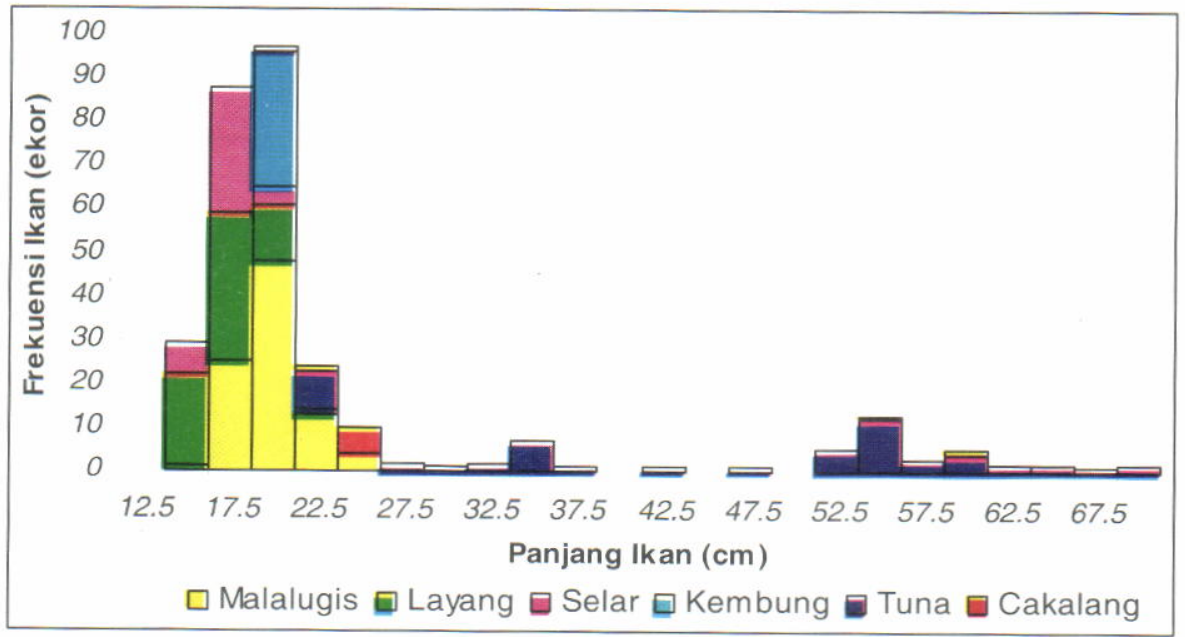

Gambar 16

Figure 16

Distribusi hasil tangkapan berdasarkan pada spesies dan ukuran ikan Distribution of catch by species and size of fish. 
sampai dengan $27,5 \mathrm{~cm}$ dengan modus $20 \mathrm{~cm}$. Selanjutnya adalah ikan layang ekor merah (Decapterus kurroides) dengan komposisi 22,97\%, dengan kisaran panjang antara 15 sampai dengan $27,5 \mathrm{~cm}$ dan memiliki modus $17,5 \mathrm{~cm}$. Ikan pelagis kecil yang lain adalah ikan selar atau bentong (Selar crumenopthalmus) dan kembung banyar (Rastrelliger kanagurta) dengan komposisi masing-masing 13,51 dan $10,81 \%$. Ikan pelagis besar didominasi oleh jenis ikan yellowfin tuna (Thunnus albacares) dan cakalang (Katsuwonus pelamis). Yellowfin tuna merupakan ikan yang berukuran besar dapat mencapai panjang $>100$ $\mathrm{cm}$. Yellowfin tuna lebih dominan dibandingkan dengan ikan cakalang dengan komposisi masingmasing 18,92 dan 3,04\% dengan kisaran panjang 17,5 sampai dengan $72,5 \mathrm{~cm}$ untuk yellowfin tuna dan 20 sampai dengan $60 \mathrm{~cm}$ untuk cakalang, sedangkan modus panjang untuk jenis yellowfin tuna dan cakalang masing-masing terletak pada 55 dan $25 \mathrm{~cm}$ seperti yang dapat dilihat pada Gambar 16 dan 17 di bawah ini.

Dari komposisi jenis ikan hasil tangkapan tersebut dapat dilihat bahwa jenis ikan yang mendominasi perairan Teluk Tomini pada periode 21 Juli sampai dengan 5 Agustus 2003 adalah jenis ikan layang, baik

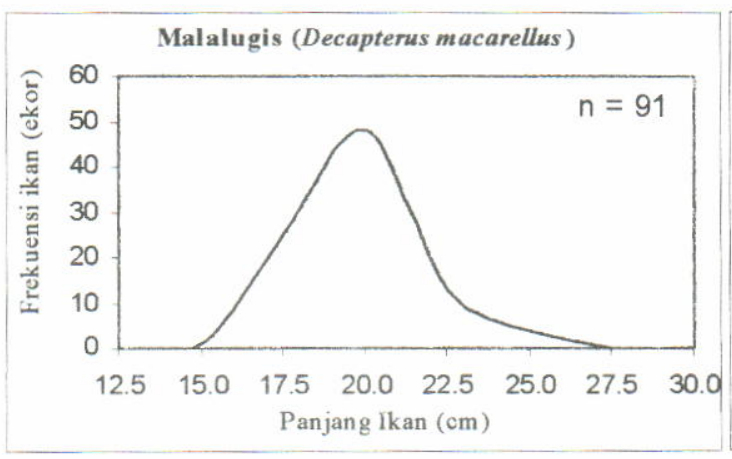

(a)

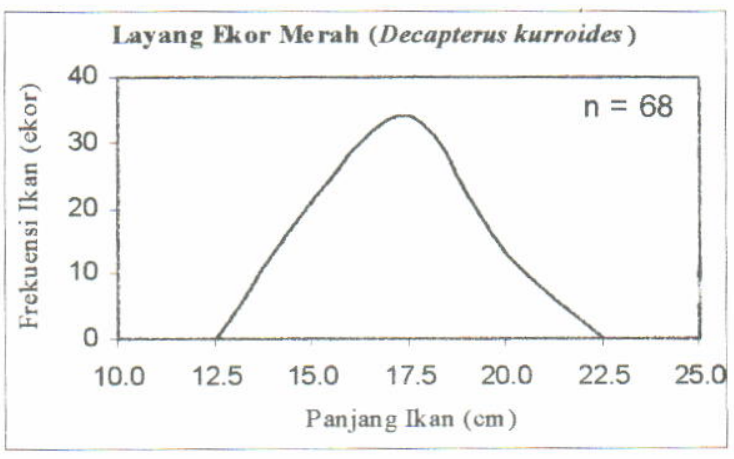

(b)

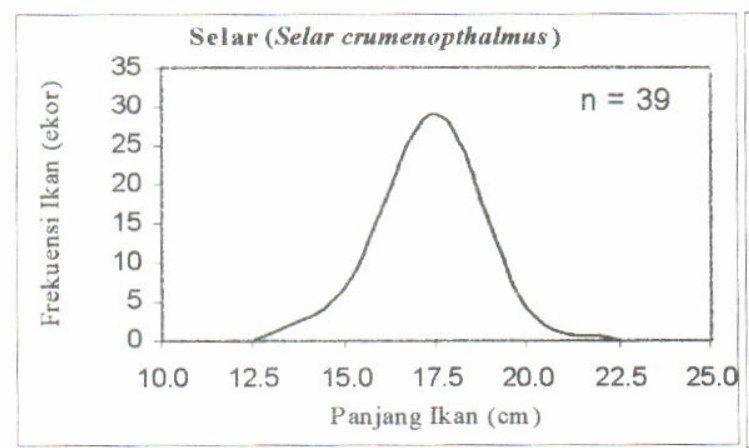

(c)

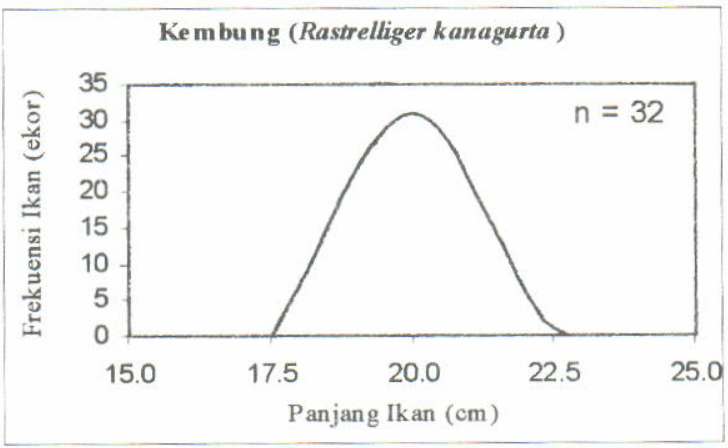

(d)

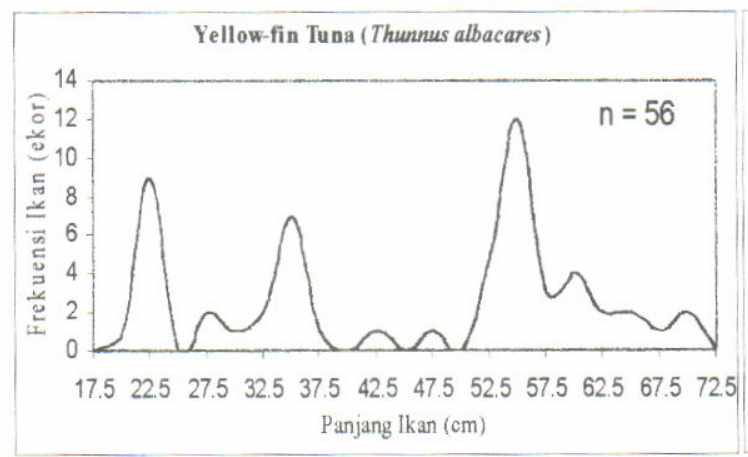

(e)

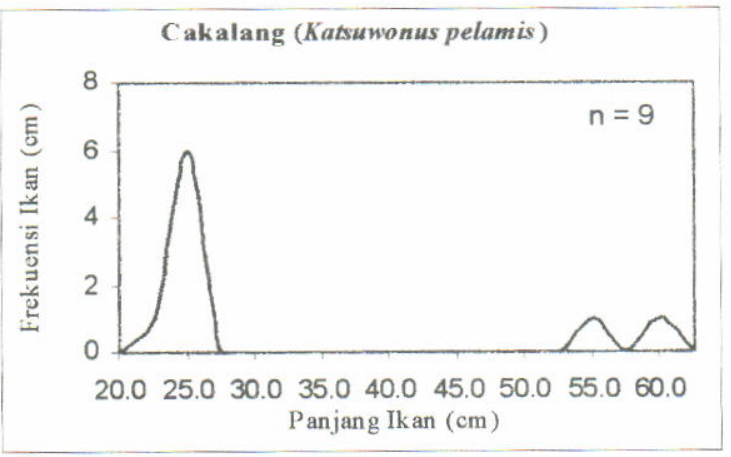

(f)

Gambar 17. Distribusi panjang dan jumlah ikan per spesies di perairan Teluk Tomini hasil pengambilan contoh selama survei akustik.

Figure 17. Distribution of length and number of fish by species in Tomini Bay caught during accoustic survey. 
ikan malalugis (Decapterus macarellus) maupun layang ekor merah (Decapterus kurroides) untuk ikan pelagis kecil. Untuk ikan pelagis besar didominasi oleh ikan dari jenis yellowfin tuna (Thunnus albacares). Baik ikan pelagis kecil maupun ikan pelagis besar yang menjadi modus hasil tangkapan, keduanya merupakan jenis ikan yang tidak memilikj gelembung renang (bladderless fish). Distribusi panjang dan jumlah ikan per spesies secara lebih jelas dapat dilihat pada Gambar 17 berikut ini.

Berdasarkan pada Gambar 18, terlihat distribusi dugaan panjang ikan hasil konversi nilai target strength berkisar antara 12,5 sampai dengan $72,5 \mathrm{~cm}$. Dari hasil konversi nilai target strength tersebut, ikan yang memiliki panjang antara 15 sampai dengan 22,5 $\mathrm{cm}$ merupakan ukuran ikan yang dominan. Berdasarkan pada ukuran panjang tersebut dapat diduga bahwa nilai target strength berasal dari jenis ikan pelagis kecil, terutama jenis ikan layang. Ikan layang yang hidup di perairan Indonesia pada umumnya memiliki ukuran panjang antara 15 sampai dengan $25 \mathrm{~cm}$, bahkan dapat mencapai panjang 30 cm (Nontji, 1987).

Distribusi panjang ikan pelagis yang diperoleh dari sistem akustik memiliki pola yang hampir sama dengan distribusi panjang ikan hasil tangkapan walaupun sedikit terjadi pergeseran nilai pada hasil pendugaan panjang ikan oleh sistem akustik (Gambar 19). Pergeseran nilai tersebut antara lain diduga salah satunya disebabkan oleh pengambilan data hasil tangkapan yang tidak secard in situ dan real time, namun demikian terdapat kesamaan di antara keduanya, yaitu frekuensi panjang ikan yang tertinggi terdapat pada kisaran antara 15 sampai dengan 25 $\mathrm{cm}$ dan frekuensi ikan semakin berkurang dengan bertambahnya ukuran panjang ikan.

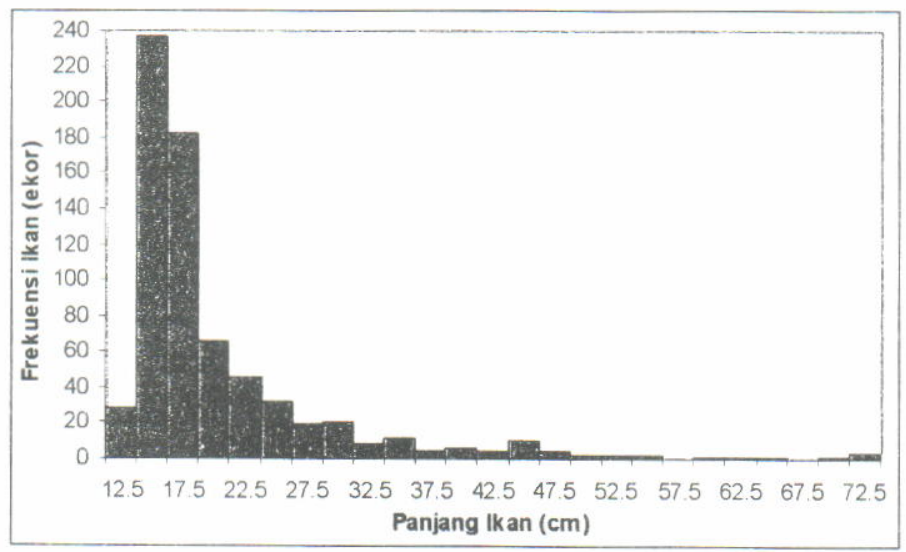

Gambar 18. Distribusi dugaan panjang ikan dengan formula Foote: $T S=20 \mathrm{Log} L+A$. Figure 18. Distribution of fish length estimation using Foote's formula: $T S=20 \mathrm{Log}+A$.

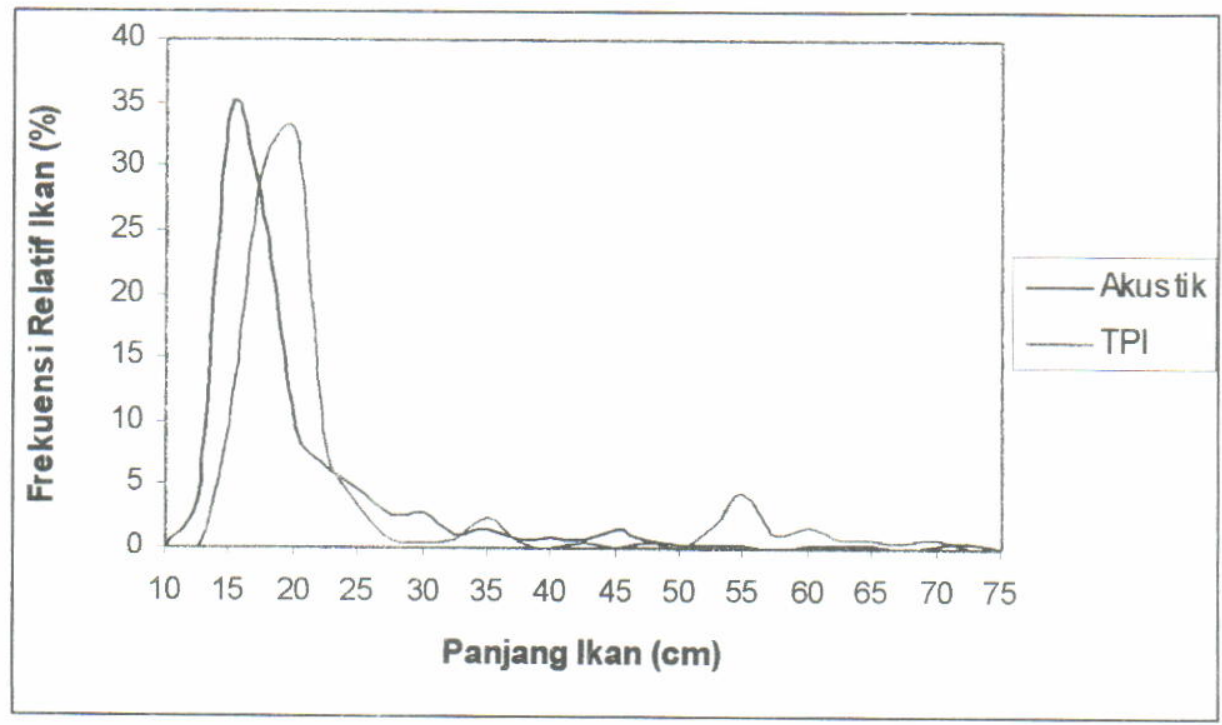

Gambar 19

Figure 19.

Distribusi frekuensi panjang ikan hasil tangkapan dan konversi nilai target strength. Length frequency distribution of fish catch and target strength conversion value. 
Dari Gambar 19, pola yang hampir sama ditunjukkan oleh distribusi panjang ikan hasil tangkapan dan hasil konversi nilai target strength. Hal ini, membuktikan bahwa sebagian besar ikan pelagis kecil dan ikan pelagis besar yang berada di perairan Teluk Tomini adalah jenis ikan yang tidak memiliki gelembung renang (bladderless fish). Oleh karena itu, sudah tepat apabila dugaan panjang ikan dari nilai target strength yang dihasilkan dengan sistem akustik di perairan Teluk Tomini ini digunakan nilai normalized target strength $-80 \mathrm{~dB}$.

\section{KESIMPULAN}

1. Pola distribusi spasial target strength ikan pelagis di perairan Teluk Tomini pada bulan Juli sampai dengan Agustus 2003 untuk kedalaman sampai dengan $250 \mathrm{~m}$ memperlihatkan kisaran nilai antara -60 sampai dengan $-30 \mathrm{~dB}$ dengan modus terdapat pada nilai target strength $-57 \mathrm{~dB}$. Secara umum, frekuensi target strength hampir merata untuk setiap strata kedalaman, dengan frekuensi tertinggi terdapat pada strata 2 (25 sampai dengan $50 \mathrm{~m}$ ). Ikan pelagis yang berukuran lebih besar cenderung untuk menempati lapisan perairan yang lebih dalam, terlihat dari distribusi nilai target strength yang lebih besar banyak terdapat pada strata 8 (175 sampai dengan 200 $\mathrm{m}$ ) sampai dengan strata 10 (225 sampai dengan $250 \mathrm{~m}$ ).

2. Secara temporal, perbedaan pola distribusi target strength lebih jelas ditunjukkan oleh ukuran ikan dibandingkan dengan jumlah ikan. Target strength dengan nilai yang besar lebih banyak terdeteksi pada malam hari dibandingkan dengan siang hari. Hal ini, diduga karena adanya migrasi harian secara vertikal yang dilakukan oleh ikanikan pelagis yang berukuran besar, seperti dari jenis tuna dan cakalang dari lapisan bawah menuju lapisan yang lebih atas untuk mencari makan atau memenuhi kebutuhan fisiologisnya.

3. Pola sebaran individu (target strength) ikan pelagis di perairan Teluk Tomini tidak banyak dipengaruhi oleh kondisi oseanografi khususnya suhu dan salinitas. Hal ini, ditunjukkan oleh tersebarnya secara hampir merata nilai-nilai target strength yang kecil pada seluruh strata kedalaman ( 5 sampai dengan $250 \mathrm{~m}$ ).
4. Berdasarkan pada hasil konversi nilai target strength, diperoleh dugaan rata-rata panjang ikan dengan kisaran antara 12,5 sampai dengan 72,5 $\mathrm{cm}$. Ukuran dugaan panjang ikan yang dominan berkisar antara 15 sampai dengan $22,5 \mathrm{~cm}$ yang merupakan ukuran umum untuk ikan dari jenis layang (Decapterus sp.). Hal ini, sesuai dengan hasil tangkapan, bahwa di perairan Teluk Tomini pada bulan Juli sampai dengan Agustus $2003 \mathrm{di}$ dominasi oleh jenis ikan layang, terutama ikan malalugis (Decapterus macarellus).

\section{DAFTAR PUSTAKA}

Foote, K. G. 1987. Fish target strength for use in echo integrator surveys. Journalist Acoustical Society of America. Vol (82): 981-987.

Gunarso, W. 1988. Tingkah laku ikan dalam hubungannya dengan alat, metoda, dan taktik penangkapan. Jurusan Pemanfaatan Sumber Daya Perikanan. Fakultas Perikanan. Institut Pertanian Bogor. Bogor. 149 hal.

Johanesson, K. A. \& R. B. Mitson. 1983. Fisheries acoustic: A practical manual for aquatic biomass estimation. FAO. Fisheries Tech. Pap. Vol. (240): $249 \mathrm{p}$.

Laevastu, T. \& M. L. Hayes. 1981. Fisheries oseanography and ecology. Fishing News (Book) Ltd. Great Britain: 60-69.

MacLennan, D. N. 1990. Acoustica! measurenment of fish abundance. Journalist Acoustical Society of America. (62): 1-15.

MacLennan, D. N. \& E. J. Simmonds. 1992. Fisheries Acoustic. Chapman \& Hall. 185-192, 215-223.

Nontji, A. 1987. Laut nusantara. Djambatan. Jakarta. 351 hal.

SIMRAD. 1993. SIMRAD EP 500 (Operational Manual). Horten-Norway.

SIMRAD. 1997. EY 500 Portable scientific echosounder. Horten-Norway.

Torne, R. E. 1983. Hydroacoustics. Fisheries techniques. p: 239-259. L. A. Nelsen \& D. L. Johnson (Eds). America Fisheries Society Betheda, Maryland. 